\title{
The Effects of Magnesium Supplementation on Subjective Anxiety and Stress-A Systematic Review
}

\author{
Neil Bernard Boyle *, Clare Lawton and Louise Dye \\ School of Psychology, University of Leeds, Leeds LS2 9JT, UK; c.l.lawton@leeds.ac.uk (C.L.); \\ 1.dye@leeds.ac.uk (L.D.) \\ * Correspondence: n.b.boyle@leeds.ac.uk; Tel.: +44-113-343-1403
}

Received: 31 January 2017; Accepted: 17 April 2017; Published: 26 April 2017

\begin{abstract}
Background: Anxiety related conditions are the most common affective disorders present in the general population with a lifetime prevalence of over $15 \%$. Magnesium $(\mathrm{Mg})$ status is associated with subjective anxiety, leading to the proposition that $\mathrm{Mg}$ supplementation may attenuate anxiety symptoms. This systematic review examines the available evidence for the efficacy of $\mathrm{Mg}$ supplementation in the alleviation of subjective measures of anxiety and stress. Methods: A systematic search of interventions with $\mathrm{Mg}$ alone or in combination (up to 5 additional ingredients) was performed in May 2016. Ovid Medline, PsychInfo, Embase, CINAHL and Cochrane databases were searched using equivalent search terms. A grey literature review of relevant sources was also undertaken. Results: 18 studies were included in the review. All reviewed studies recruited samples based upon an existing vulnerability to anxiety: mildly anxious, premenstrual syndrome (PMS), postpartum status, and hypertension. Four/eight studies in anxious samples, four/seven studies in PMS samples, and one/two studies in hypertensive samples reported positive effects of $\mathrm{Mg}$ on subjective anxiety outcomes. Mg had no effect on postpartum anxiety. No study administered a validated measure of subjective stress as an outcome. Conclusions: Existing evidence is suggestive of a beneficial effect of $\mathrm{Mg}$ on subjective anxiety in anxiety vulnerable samples. However, the quality of the existing evidence is poor. Well-designed randomised controlled trials are required to further confirm the efficacy of $\mathrm{Mg}$ supplementation.
\end{abstract}

Keywords: magnesium; anxiety; stress; intervention

\section{Introduction}

Magnesium (Mg) is an essential mineral utilized in the human body, as a cofactor, by in excess of 300 biochemical reactions required to maintain homeostasis [1]. The biological functions of $\mathrm{Mg}$ are broad and varied, and include the production of nucleic acids, involvement in all adenosine triphosphate (ATP) fueled reactions, and modulation of any activity mediated by intracellular calcium concentration fluxes (e.g., insulin release, muscle contraction [2]).

Dietary intake of $\mathrm{Mg}$ has been shown to be insufficient in Western populations [3-5]. Sixty-eight percent of Americans [3] and 72\% of middle aged French adults [6] have been shown to consume less than the recommended levels of dietary $\mathrm{Mg}$. This inadequate intake is linked with an array of poor health outcomes including hypertension [7], cardiovascular disease [8], and type II diabetes [9].

Depletion and supplementation studies in animals and humans suggest that $\mathrm{Mg}$ may play an important part in the etiology of affective mood disorders. A relationship between $\mathrm{Mg}$ and affective depressive states has been established (for reviews see $[10,11]$ ). Magnesium plays a key role in the activity of psychoneuroendocrine systems and biological and transduction pathways associated with the pathophysiology of depression. For example, all elements of the limbic-hypothalamuspituitary-adrenocortical axis are sensitive to the action of Mg [12]. Magnesium has also been 
demonstrated to suppress hippocampal kindling [13,14], attenuate the release of, and affect adrenocortical sensitivity to, adrenocorticotrophic hormone (ACTH) [15,16], and may influence the access of corticosteroids to the brain at the level of the blood brain barrier via its action on p-glycoprotein [17-19].

Experimentally induced hypomagnesemia results in depression like behavior in rodents [20-23] which is effectively treated by administration of antidepressants [21,23]. An impoverished Mg diet is associated with depression in humans [24]. Low serum and cerebrospinal fluid $\mathrm{Mg}$ levels have also been associated with depressive symptomology [25] and suicidality [26]. However, further evidence of a relationship between raised $\mathrm{Mg}$ levels and depressive states [27-29] suggests the relationship between $\mathrm{Mg}$ levels and depression is yet to be fully elucidated.

Further support for a relationship between $\mathrm{Mg}$ and affective states comes from evidence of the efficacy of $\mathrm{Mg}$ supplementation in the treatment of depression. Magnesium intake reduces depression-related behaviour in mice [30] and is effective as an adjunctive treatment for depression in rodent models [31,32]. In humans, 12 weeks intake of $450 \mathrm{mg}$ of elemental $\mathrm{Mg}$ has been shown to be as effective in reducing depression symptoms as a tricyclic antidepressant (Imipramine $50 \mathrm{mg}$ ) in depressed hypomagnesic elderly patients with type II diabetes [33]. Further evidence from case studies suggests $\mathrm{Mg}$ is an effective adjunctive therapy for treating major depression [34,35]. However, the efficacy of $\mathrm{Mg}$ in the treatment of depression symptomology has not been consistently reported [36]. Mood stabilizing effects of $\mathrm{Mg}$ supplementation have also been reported in additional clinical samples, including the improvement of clinical signs of mania [37], rapid cycling bipolar disorder [38], and alleviation of affective symptoms associated with chronic fatigue syndrome [39].

Depression is often comorbid with anxiety [40]. Anxiety related conditions are the most common affective disorders present in the general population with a lifetime prevalence of over 15\% [41]. The anxiolytic potential of $\mathrm{Mg}$ has been demonstrated in rodent models. Naturally and experimentally induced hypomagnesemia elevates anxiety states in mouse models [12,21,42,43]. Blood plasma and brain $\mathrm{Mg}$ levels are also significantly correlated with anxiety-related behavioral responses in rodents [44]. Supplementing Mg levels in mice has been demonstrated to reduce the expression of anxiety-related behavior [30,45].

A relationship between $\mathrm{Mg}$ status and anxiety is evident in humans. Test anxiety, related to exposure to stressful exam conditions, increases urinary $\mathrm{Mg}$ excretion, resulting in a partial reduction of $\mathrm{Mg}$ levels [46]. Further, dietary levels of $\mathrm{Mg}$ intake have been modestly inversely associated with subjective anxiety in a large community-based adult sample [24]. Magnesium also modulates activity of the hypothalamic pituitary adrenal axis (HPAA) which is a central substrate of the stress response system. Activation of the HPAA instigates adaptive autonomic, neuroendocrine, and behavioral responses to cope with the demands of the stressor; including increasing anxiety. Exposure to stress moderates serum (noise stress; [47]) and intracellular (exam stress; [48]) Mg levels. Magnesium supplementation has also been shown to attenuate the activity of the HPAA, including a reduction in central (ACTH; [15]) and peripheral (cortisol; [49]) endocrine responses of this system. Therefore, $\mathrm{Mg}$ may further influence anxiety states via the moderation of the stress response.

A number of potential mechanistic pathways have been described which may account for the relationship between $\mathrm{Mg}$ and anxiety. Glutamate is the primary excitatory neurotransmitter in the mammalian brain. Glutamate acts on $\mathrm{Ca}^{2+}$ channel coupled N-methyl-D-aspartate (NMDA) ionotropic receptors which have been implicated in anxiety and panic disorders [50]. Magnesium reduces neuronal hyperexcitability by inhibiting NMDA receptor activity [51]. Magnesium is also essential for the activity of mGluRs-G-protein coupled receptors that are widely expressed in the brain [52,53]. The mGluRs receptors play a key modulatory role in glutamatergic activity, secretion and presynaptic release of glutamate, activity of the GABA ( $\gamma$-aminobutyric acid)ergic system, and regulation of the neuroendocrine system. The action of glutamate on mGluRs receptors has been implicated in responses to fear, anxiety and panic [53]. Magnesium may additionally modulate anxiety via increasing GABAergic availability by decreasing presynaptic glutamate release [54]. GABA is a primary inhibitory transmitters in the CNS that counterbalances the excitatory action of glutamate. An imbalance between 
GABA and glutamate is associated with neuronal hyperexcitability characteristic of pathological anxiogenesis [55].

Evidence of the association between $\mathrm{Mg}$ and anxiety has increased interest in the potential efficacy of $\mathrm{Mg}$ intake to attenuate anxiety symptoms. Prevalent pharmaceutical anxiolytic treatments for clinical anxiety (e.g., benzodiazepines) are often characterized by multiple negative side-effects for many patients. Therefore, the identification of new efficacious treatments to alleviate symptoms of anxiety has great utility. This systematic review summarises the current available evidence for the efficacy of $\mathrm{Mg}$ supplementation in the alleviation of subjective measures of anxiety. Considering the conceptual and psychoneuroendocrine overlap between anxiety and stress, the review will also examine evidence for potential effects of $\mathrm{Mg}$ intake on parameters of subjective stress. A previous systematic review of the effects of nutritional and herbal supplements on anxiety and anxiety-related disorders summarised the findings of three $\mathrm{Mg}$ intervention studies [56]. However, this review summarised the literature prior to 2010 and, since searches were limited to only two databases, likely failed to identify all relevant publications. Therefore, this is the first systematic review of the relationship between $\mathrm{Mg}$ supplementation and subjective anxiety and stress.

\section{Materials and Methods}

\subsection{Selection of Studies}

The research synthesis was limited to intervention studies in human adult samples ( $\geq 18$ years old.) that administered a $\mathrm{Mg}$ dose in isolation or combined with a maximum of 5 additional ingredients, and reported an outcome measure of subjective anxiety or stress. This included any general subjective measure that included subscales related to stress and anxiety symptomology. Intervention studies examining acute and chronic effects of $\mathrm{Mg}$ manipulations were included. Studies examining the effects of $\mathrm{Mg}$ depletion (in the absence of an intervention) or increased consumption of diets associated with high Mg content were excluded. Studies reporting effects in individuals with significant health conditions (e.g., cancer, chronic fatigue syndrome) and developmental disorders (e.g., autism) were excluded. Samples recruited on the basis of mild to moderate subjective anxiety, hypertension, or subjective symptoms associated with premenstrual syndrome (PMS), were retained. The efficacy of $\mathrm{Mg}$ intake has been examined as a novel and adjunct treatment approach for depression. This literature has been adequately summarised in a number of previous systematic reviews (e.g., [10,11]). Therefore, studies reporting the effects of $\mathrm{Mg}$ intake in depressed samples are not reviewed here. Publications were required to be in the English, French or German languages to permit review by authors. Studies failing to report sufficient detail to permit accurate characterisation of the methodological approach were also not included in the review. Minimum reporting requirements were sample size and composition, $\mathrm{Mg}$ dose and intervention length, and clearly defined outcome measures of subjective anxiety or stress.

\subsection{Literature Search}

To identify relevant studies, computerised database searches were conducted in May 2016 on OVID MEDLINE (inclusive of records 1946-2016 and non-indexed citations, 2016), PsycINFO (inclusive of records 1806-2016), EMBASE (inclusive of records 1806-2016, CINAHL (inclusive of records 1960-May 2016), and the databases comprised under EBM REVIEWS (inclusive of records 1991-2016). The following search terms were used: 'Magnesium\$'; OR 'Epsom'; OR 'Mg citrate'; OR 'Mg oxide'; OR 'Mg sulphate'; OR 'Mg lysinate'; OR 'Mg glycinate'; OR 'Mg bicarbonate'; OR 'Mg carbonate'; OR 'Mg chloride'; OR 'Mg hydroxide'; 'Mg phosphate'; OR 'Mg ascorbate'; OR 'Mg aspartate'; OR 'Mg fumarate'; OR 'Mg gluconate'; OR 'Mg glutamate'; OR 'Mg lactate'; $\mathrm{OR}$ 'Mg malate'; OR 'Mg pidolate'; OR 'Mg orotate'; OR 'Mg taurate' AND 'Stress\$'; OR 'Strain'; OR 'Tension'; OR 'Cortisol'; OR 'Anxi\$'; OR 'Worry'; OR 'Mood'. For searches of OVID MEDLINE, PSYCH INFO, EMBASE the search field (tw-text word) was applied to all search terms. The search field (tx-full 
text) was applied for searches of CINAHL and EBM REVIEWS. The additional filter 'Human' was added to all searches where supported. The reference lists of existing reviews and identified articles were hand searched to supplement the electronic searches.

The database searches returned at total of 6573 articles. Publication titles were reviewed to remove patently irrelevant and duplicate papers, leaving a total of 2094 articles selected for abstract review. The full text versions of 48 articles were retrieved and examined for eligibility. A further 34 articles were excluded (reasons for exclusion are shown in Figure 1) leaving 14 studies that met the review criteria.

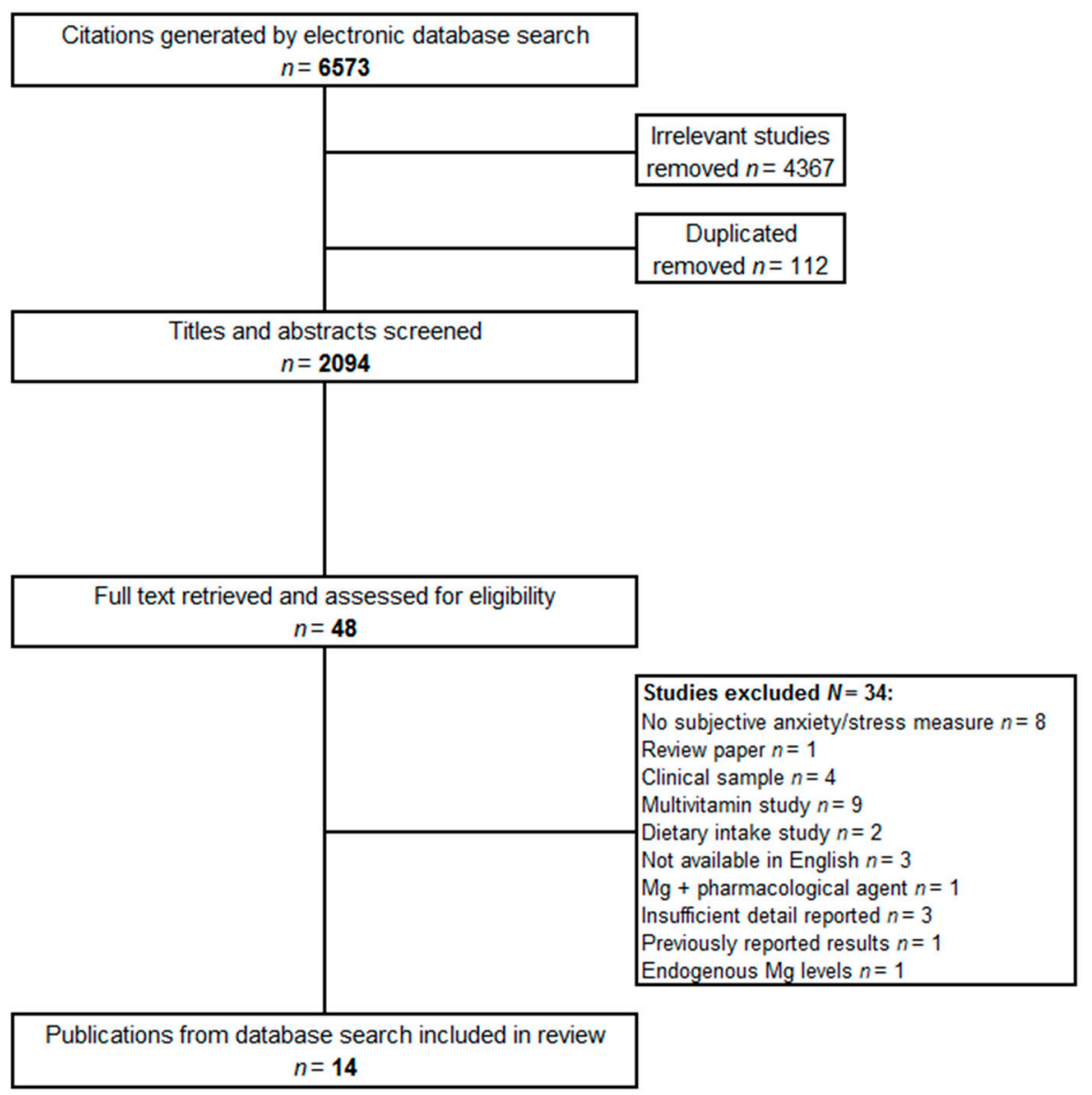

Figure 1. Electronic database study selection summary.

A grey literature search was also undertaken (September 2016) using grey literature search engines, a google scholar search, and targeted websites using the search terms 'magnesium' AND 'anxiety' OR 'stress'. A full list of employed grey literature resources is shown in Appendix A. A request for unpublished data was also published in Magnesium Research [57] and circulated on Researchgate.net. A total of 10,395 citations were screened for relevance. A summary of the grey literature search is shown in Figure 2. The search returned 4 relevant studies which were included in the review. All 4 studies were unpublished in full form at the time of the search. One study is cited in a European Food Safety Authority (EFSA) scientific opinion claim on Mg supplementation [58]. Three internal studies conducted by Sanofi S.A were included in the review. A conference abstract of the Rouillon et al. study was published in 1995 [59]. Two studies by Caillard [60,61] have not been published. Full data from these studies were provided by Sanofi, France. A short summary of these data has been published previously [62]. 


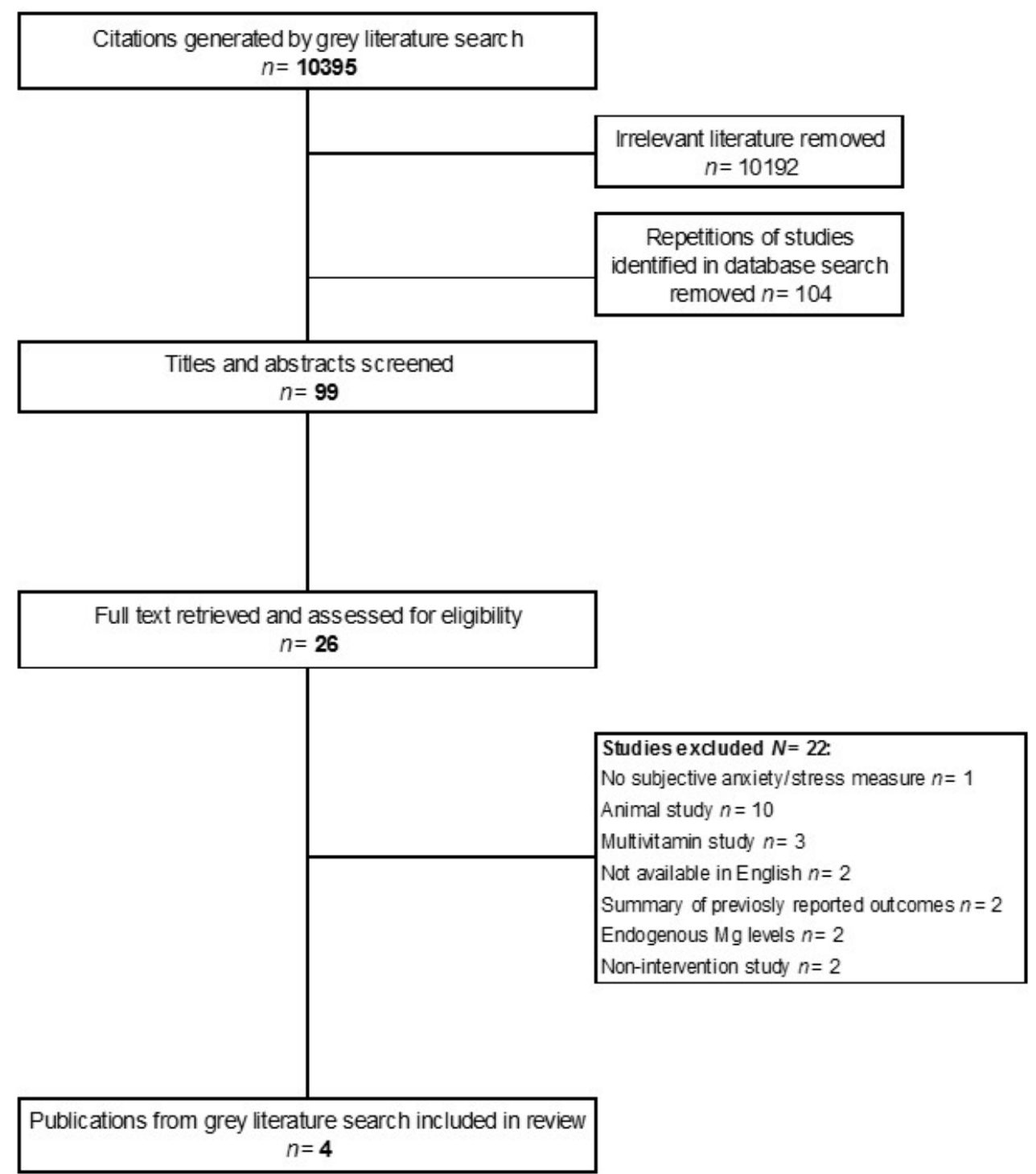

Figure 2. Grey literature search study selection summary.

\subsection{Data Extraction}

The following information was extracted from the reviewed studies:

Study Design: the experimental designs employed in each study were coded as randomised controlled trial (RCT); parallel groups (P); randomised crossover (R-Cross); and non-randomised crossover (NR-Cross). Condition: all of the reviewed studies recruited samples based upon a specific inclusion criterion; namely, mild to moderate subjective anxiety, premenstrual syndrome (PMS), $<48 \mathrm{~h}$ postpartum, and mild hypertension. The specific inclusion criterion, and the measure/method employed to identify suitable samples, were extracted. Sample Characteristics: the sample size and composition (male $(\mathrm{M})$, female $(\mathrm{F})$, mixed $(n \mathrm{M}: n \mathrm{~F})$ ), and age (mean, SD and range reported if available). Treatment: the form (when reported) and dose of $\mathrm{Mg}$ administered and additional ingredients were reported in milligrams (mg). Control: the type of control, if employed, administered (e.g., placebo, active verum). Duration: the length of time the $\mathrm{Mg}$ intervention was administered. Results: a summary of the analyses including means and SDs (if reported) of any significant findings. Effect Summary: the reported effects of $\mathrm{Mg}$ administration were summarised as positive effect $(+)$, no effect $(\times)$, negative effect $(-)$, and (?) if there exists some doubt regards the reported outcome. 


\section{Results and Discussion}

From the 18 studies meeting the review inclusion criteria, ten recruited mixed sex samples. Eight studies that examined the effects of Mg intake on PMS symptomology, and one study assessing postpartum anxiety, recruited female samples. The Mg doses administered ranged from 46.4-600 mg. Only one study adjusted a $\mathrm{Mg}$ dose relative to body weight (intravenous $\mathrm{Mg}$ sulphate infusion $0.1 \mathrm{mmol} / \mathrm{kg}$; [63]) and one study considered potential dose response effects (administering 200, 350, and $500 \mathrm{mg}$ doses; [64]). Magnesium lactate was the most commonly administered $\mathrm{Mg}$ form ( $n=5$ studies) followed by $\mathrm{Mg}$ oxide $(n=4)$. Seven studies combined $\mathrm{Mg}$ with vitamin $\mathrm{B}_{6}$ and two studies administered $\mathrm{Mg}$ with extract of Hawthorn.

All the reviewed studies recruited samples based upon specific anxiety 'vulnerability' criteria. Eight studies recruited individuals reporting mild to moderate subjective anxiety; the majority of which (6/8 studies) applied a score range of 10-30 on the Hamilton Anxiety Scale (HAM-A) [65] as an eligibility criterion. Seven studies recruited women reporting mild to moderate PMS symptoms. Eligibility was determined during menstrual cycle(s) prior to study entry using the Moos Menstrual Distress Questionnaire [66], menstrual health questionnaires [67], or subjective report. One study examined the effects of $\mathrm{Mg}$ intake on postpartum anxiety ratings [68]. Two studies recruited participants with mild hypertension, defined as diastolic blood pressure (BP) 85-100 $\mathrm{mmHg}$ [69], or diastolic and systolic $\mathrm{BP}>90 \mathrm{mmHg}$ and $140 \mathrm{mmHg}$ respectively [70].

No study administered a validated measure of subjective stress as an outcome. A number of general well-being measures were employed that included stress-related subscales (e.g., tension, concerns about the future). However, these offer insufficient evidence to form any valid judgement on the efficacy of $\mathrm{Mg}$ on subjective measures of stress. Validated measures of subjective anxiety (e.g., HAM-A; Spielberger State Trait Anxiety Inventory (STAI) [71]), and menstrual symptom and general well-being measures which included subscales specifically related to subjective anxiety (e.g., Moos Menstrual Distress Questionnaire (MDQ) [66]) were employed. Evidence of the effect of $\mathrm{Mg}$ intake on subjective anxiety outcomes is reviewed separately for each anxiety vulnerability subgroup type.

\subsection{Mild Anxiety}

A summary of studies examining the effects of $\mathrm{Mg}$ intake in anxious samples is shown in Table 1. Three of the eight studies which recruited samples based upon pre-existing levels of mild subjective anxiety reported positive effects of $\mathrm{Mg}$ supplementation on anxiety outcomes. Two unpublished RCTs compared six weeks administration of $192 \mathrm{mg} \mathrm{Mg}$ lactate + vitamin $\mathrm{B}_{6}(20 \mathrm{mg})$ vs. placebo. A greater change from baseline reduction in the HAM-A ratings after 21 days of $\mathrm{Mg}+$ vitamin $\mathrm{B}_{6}$ intake compared to the placebo was reported $(p<0.03 ;[60])$. However, this superiority of $\mathrm{Mg}$ over placebo was not maintained after 42 days. A RCT, identical in design and dose, in a larger sample focussed on the somatic features of anxiety. This reported significantly lowered somatic anxiety symptoms on the HAM-A scale after $21(p<0.004)$ and $42(p<0.02)$ days treatment with $\mathrm{Mg}+$ vitamin $\mathrm{B}_{6}$ vs. placebo ([61]). Whilst both studies demonstrated a greater reduction in anxiety after $\mathrm{Mg}+\operatorname{vitamin} \mathrm{B}_{6}$ compared to placebo, a sizeable placebo effect was also evident.

Hanus et al. [72] reported positive effects of 12 weeks intake of $75 \mathrm{mg} \mathrm{Mg}$ combined with Hawthorn (75 mg) and California poppy (20 mg) extracts vs. a placebo in individuals reporting mild anxiety or symptoms of general anxiety disorder. Consistent positive effects on three anxiety outcome measures were reported. A significant decrease from baseline in HAM-A total anxiety score was demonstrated in both $\mathrm{Mg}$ and placebo conditions after 90 days intake. However, the effect was significantly greater in the $\mathrm{Mg}$ treatment group ( $p=0.005)$. A comparable pattern of effect was shown for HAM-A somatic anxiety $(p=0.054)$. Both $\mathrm{Mg}$ treatment and placebo also demonstrated a significant reduction from baseline after 90 days on a subjective anxiety visual analogue scale (VAS). The reduction was again greater in the treatment group $(p=0.005)$. Finally, a physician global impression rating, a subjective 
efficacy ratio rating of the benefit vs. risk of a treatment, was significantly higher for Mg treatment vs. placebo $(p=0.0018)$.

Cazaubiel and Desor [58] reported a significant reduction in the anxiety subscale of the Hospital Anxiety and Depression Scale (HADS; [73]) in a mildly anxious sample following 4 weeks intake of a fermented milk drink combined with $48 \mathrm{mg} \mathrm{Mg}$. However, this finding can be considered unreliable as it reflects a post hoc analysis on restricted data (post hoc re-categorisation of 'mild stress') in a reduced subsample $(n=15)$.

Three studies compared $\mathrm{Mg}+$ vitamin $\mathrm{B}_{6}$ with a pharmaceutical anxiolytic as a positive verum. Two studies compared six weeks intake of $300 \mathrm{mg} \mathrm{Mg}$ lactate + vitamin $\mathrm{B}_{6}(20 \mathrm{mg}) \mathrm{vs} .3 \mathrm{mg}$ [74] or $2 \mathrm{mg}$ [75] of Lorazepam vs. Lorazepam combined with $300 \mathrm{mg} \mathrm{Mg}+$ vitamin $\mathrm{B}_{6}$. A reduction in HAM-A rating was evident in all treatments but no significant differences between the conditions were found. Similarly, despite a reduction in ratings in both conditions, Rouillon, Lejoyeux, \& Martineau [59] found no significant difference between $192 \mathrm{mg} \mathrm{Mg}$ lactate + vitamin $\mathrm{B}_{6}$ vs. $40 \mathrm{mg}$ Buspirone on HAM-A ratings after 6 weeks intake. An initial 7 day placebo washout period was employed prior to full study participation in this study to remove participants that exhibited sizeable placebo effects ( $\geq 50 \%$ improvement in total HAM-A score). Comparable efficacy with pharmaceutical anxiolytics may be considered evidence to support the positive effect of $\mathrm{Mg}$ on subjective anxiety. However, the lack of placebo control in these studies should be noted, particularly in the light of the significant placebo response seen in the 3 studies in which a placebo was administered. Further, the addition of a positive verum in studies that did administer a placebo control, which would have permitted both a non-active, and a proven, active comparison, would have provided a more distinct measure of the efficacy of Mg.

The final study reporting no effects of $\mathrm{Mg}$ compared pre-exam test anxiety in university students after 5 days intake of $300 \mathrm{mg} \mathrm{Mg}$ citrate vs. placebo [76]. The authors categorised participants into four anxiety groups based on subjective ratings prior to the intervention, ranging from normal to very high subjective anxiety. No differences between anxiety ratings (STAI) on the eve of the exam were found between conditions or as a function of anxiety group categorisation. This lack of effect may be due to contextual differences in the form of anxiety examined. Whilst positive evidence of the anxiolytic effects of $\mathrm{Mg}$ has been shown in chronically anxious samples (i.e., those demonstrating moderate anxiety scores on the HAM-A), Gendle et al. [76] examined the effects of Mg on responses to an acute, anxiety-provoking situation-specific context. Whilst the authors did take into account pre-existing levels of anxiety in the sample, this was ascertained by the Westside Test Anxiety Scale [77] which is a short measure specifically designed to assess exam-specific, not clinical, anxiety and was used as a covariate in the analysis rather than to select an anxiety vulnerable sample. Therefore, both the context and sample differ from the other studies reviewed which recruited chronically anxious individuals using a clinical measure; the HAM-A.

Examining the efficacy of $\mathrm{Mg}$ to reduce subjective anxiety in anxious individuals is a valid approach. The positive effects of nutritional interventions are often demonstrated in those with specific pre-existing vulnerabilities (e.g., low socio-economic status [78]; low IQ [79]; high neuroticism [80]). However, six out of eight studies examining the effects of $\mathrm{Mg}$ intake in anxious samples employed the HAM-A both as an inclusion criterion and primary outcome variable. This practice has the effect of constraining the variance of responses at inclusion, increasing the likelihood of regression to the mean post-intervention [81] and may therefore mask some of the true effect if it exists in the population [82]. The employment of a measure to identify anxious samples that is distinct from the subjective anxiety outcome measure is preferable. 
Table 1. Summary of studies reporting the effects of $\mathrm{Mg}$ on subjective anxiety/stress in mild to moderately anxious individuals.

\begin{tabular}{|c|c|c|c|c|c|c|c|c|c|c|c|}
\hline Author & $\begin{array}{c}\text { Study } \\
\text { Design }\end{array}$ & Condition & $\begin{array}{c}\text { Sample } \\
(N)\end{array}$ & Sex & Age (year) & Treatment (s) & Control & Duration & $\begin{array}{l}\text { Outcome } \\
\text { Measure }\end{array}$ & Results & $\begin{array}{l}\text { Effect } \\
\text { Summary }\end{array}$ \\
\hline Bourgeois et al. [74] & RCT & $\begin{array}{l}\text { Mild anxiety (Hamilton } \\
\text { Anxiety Scale } \\
\text { score 10-30) }\end{array}$ & $\begin{array}{c}N=81 \\
(n=27 \text { per } \\
\text { condition })\end{array}$ & 20M:61F & $18-65$ & $\begin{array}{l}\text { (i) } \mathrm{Mg} 300 \mathrm{mg} \text { as } \\
\text { lactate + vit } \mathrm{B}_{6} 750 \mathrm{mg} \text {; } \\
\text { (ii) } \text { orazepam } 3 \mathrm{mg} ; \\
\text { (iii) (i) + (ii) combined } \\
\end{array}$ & $\begin{array}{l}\text { Lorazepam } \\
3 \mathrm{mg} \\
\text { (positive } \\
\text { verum) } \\
\end{array}$ & 6 weeks & $\begin{array}{l}\text { Hamilton } \\
\text { Anxiety } \\
\text { Scale }\end{array}$ & $\begin{array}{l}\text { Reduced anxiety scores in all treatments. } \\
\text { No significant differences } \\
\text { between treatments. }\end{array}$ & $\mathrm{x}^{*}$ \\
\hline Scharbach [75] & RCT & $\begin{array}{l}\text { Mild anxiety (Hamilton } \\
\text { Anxiety Scale } \\
\text { score 15-30) }\end{array}$ & $\begin{array}{l}N=133 \\
\text { (Treatments } \\
\text { (i) } n=44 ; \\
\text { (ii) } n=46 ; \\
\text { (ii) } n=43 \text {; }\end{array}$ & 32M:109F & $18-65$ & $\begin{array}{l}\text { (i) } \mathrm{Mg} 300 \mathrm{mg} \text { as } \\
\text { lactate + vit } \mathrm{B} 6750 \mathrm{mg} \text {; } \\
\text { (ii) Lorazepam } 2 \mathrm{mg} \text {; } \\
\text { (iii) (i) + (ii) combined }\end{array}$ & $\begin{array}{l}\text { Lorazepam } \\
2 \mathrm{mg} \\
\text { (positive } \\
\text { verum) }\end{array}$ & 6 weeks & $\begin{array}{l}\text { Hamilton } \\
\text { Anxiety } \\
\text { Scale }\end{array}$ & $\begin{array}{l}\text { Reduced anxiety scores in all treatments. } \\
\text { No significant differences } \\
\text { between treatments. }\end{array}$ & $x^{*}$ \\
\hline Caillard [60] & RCT & $\begin{array}{c}\text { Mild anxiety/general } \\
\text { anxiety disorder } \\
\text { (Hamilton Anxiety Scale } \\
\text { score 15-30 \& general } \\
\text { anxiety disorder (DSM } \\
\text { III criteria)) }\end{array}$ & $N=93$ & 25M:68F & $\begin{array}{c}x=41(\mathrm{SD} \\
=12 ; 18-65)\end{array}$ & $\begin{array}{l}\mathrm{Mg} 192 \mathrm{mg} \text { as lactate + } \\
\text { vit } \mathrm{B}_{6} 20 \mathrm{mg}\end{array}$ & Placebo & 6 weeks & $\begin{array}{l}\text { Hamilton } \\
\text { Anxiety } \\
\text { Scale }\end{array}$ & $\begin{array}{c}\text { Significant change from baseline (Total } \\
\text { score) between groups at Day } 21(\mathrm{Mg}+ \\
\text { vit } \mathrm{B}_{6}: x=12.1(\mathrm{SD}=6.0) \text {; placebo: } x= \\
15.5(\mathrm{SD}=5.8)) \text { vs. Day } 0\left(\mathrm{Mg}+\text { vit } \mathrm{B}_{6}: x\right. \\
=21.0(\mathrm{SD}=4.5) \text {; placebo: } x=22.6(\mathrm{SD}= \\
4.4) ; p<.03) \text {. No significant differences } \\
\text { between Day } 0 \text { \& Day } 42 .\end{array}$ & + \\
\hline Rouillon et al., [59] & RCT & $\begin{array}{c}\text { Mild anxiety/general } \\
\text { anxiety disorder } \\
\text { Hamilton Anxiety Scale } \\
\text { score 15-30 \& general } \\
\text { anxiety disorder (DSM } \\
\text { III-R criteria)) }\end{array}$ & $\begin{array}{c}N=99(\mathrm{Mg} \\
n=51 \\
\text { Buspirone } \\
n=48)\end{array}$ & 38M:61F & $\begin{array}{c}x=37.7 \\
(\mathrm{SD}=10.7 \\
19-65)\end{array}$ & $\begin{array}{l}\mathrm{Mg} 192 \mathrm{mg} \text { as lactate + } \\
\text { vit } \mathrm{B}_{6} 20 \mathrm{mg}\end{array}$ & $\begin{array}{l}\text { Buspirone } \\
40 \mathrm{mg} \\
\text { (positive } \\
\text { verum) }\end{array}$ & 6 weeks & $\begin{array}{l}\text { Hamilton } \\
\text { Anxiety } \\
\text { Scale }\end{array}$ & $\begin{array}{l}\text { Decrease in anxiety scores in both } \\
\text { treatment groups across intake. No } \\
\text { significant difference between the } \\
\text { efficacy of } \mathrm{Mg}+\text { vit } \mathrm{B}_{6} \& \text { Buspirone. }\end{array}$ & $x^{*}$ \\
\hline Caillard [61] & RCT & $\begin{array}{c}\text { Symptoms of functional } \\
\text { impairment associated } \\
\text { with anxiety or a } \\
\text { somatic disorder } \\
\text { (Hamilton Anxiety Scale } \\
1 \text {; Raskin depression } \\
\text { scale }<7 \text {; COVI anxiety } \\
\text { scale }=7 \text { ) }\end{array}$ & $N=103$ & $26 \mathrm{M}: 77 \mathrm{~F}$ & $\begin{array}{l}x=37 \\
(18-65)\end{array}$ & $\begin{array}{l}\mathrm{Mg} 192 \mathrm{mg} \text { as lactate + } \\
\text { vit } \mathrm{B}_{6} 20 \mathrm{mg}\end{array}$ & Placebo & 6 weeks & $\begin{array}{l}\text { Hamilton } \\
\text { Anxiety } \\
\text { Scale } \\
\text { (somatic } \\
\text { score) }\end{array}$ & $\begin{array}{c}\text { Significantly lower somatic anxiety } \\
\text { rating after treatment at Day } 21(x=8.4 \\
(\mathrm{SD}=3.8) ; p=0.004) \& \text { Day } 42(x=6.5 \\
(\mathrm{SD}=3.0) ; \mathrm{p}=0.02) \text { vs. placebo (Day 21: } \\
x=9.9(\mathrm{SD}=2.9) ; \text { Day } 42: x=7.8 \\
(\mathrm{SD}=3.6)) .\end{array}$ & + \\
\hline Hanus et al. [72] & RCT & $\begin{array}{l}\text { Mild anxiety/general } \\
\text { anxiety order (Hamilton } \\
\text { Anxiety Scale score } \\
\text { 16-28 \& somatic score } \geq \\
50 \% \text { total score; \& } \\
\text { general anxiety } \\
\text { disorder) DSM-III-R)) }\end{array}$ & $\begin{array}{c}N=264 \\
\text { (Treatment } \\
n=130 \\
\text { Placebo } n= \\
134 \text { ) }\end{array}$ & 26M:213F & $\begin{array}{l}\text { Placebo: } x \\
=44.5 \\
\text { (18-82); } \\
\text { Treatment: } \\
x=44.8 \\
(19-81)\end{array}$ & $\begin{array}{l}\text { Hawthorn extract } 75 \\
\mathrm{mg} \text {, California poppy } \\
20 \mathrm{mg} \text { + elemental } \mathrm{Mg} \\
75 \mathrm{mg}\left(\text { Sympathyl } \mathrm{l}^{\mathbb{}}\right)\end{array}$ & Placebo & 12 weeks & $\begin{array}{l}\text { Hamilton } \\
\text { Anxiety } \\
\text { Scale } \\
\text { Self-reported } \\
\text { anxiety } \\
\text { (100 mm } \\
\text { VAS) } \\
\text { Physician } \\
\text { global } \\
\text { impression }\end{array}$ & $\begin{array}{c}\text { Total anxiety score: Significant decrease } \\
\text { in both conditions. Effect larger in } \\
\text { treatment group. Mean change from } \\
\text { baseline between Day } 0 \& \text { Day } 90 \\
\text { significantly greater in treatment group } \\
(x=-10.6(\mathrm{SD}=1.2)) \text { vs. placebo } \\
(x=-8.9 \text { (SD }=1.2) ; p=0.005) \text {. Somatic } \\
\text { score change from baseline: Treatment } \\
(x=-6.5 \text { (SD }=0.7)) \text { Placebo }(x=-5.7 \\
\text { (SD }=0.7) ; p=0.054) \text {. Self-rated anxiety } \\
\text { VAS: Mean change from baseline } \\
\text { between Day o \& Day } 90 \text { significantly } \\
\text { greater in treatment group }(x=-38.5 \text { vs. } \\
\text { placebo }(x=-29.2 ; p=0.005) \text {. Physician } \\
\text { global impression: benefit }>\text { risk rating } \\
\text { significantly greater in treatment }(90 \%) \\
\text { vs. placebo }(80 \% ; p=0.0018) .\end{array}$ & + \\
\hline
\end{tabular}


Table 1. Cont.

\begin{tabular}{|c|c|c|c|c|c|c|c|c|c|c|c|}
\hline Author & $\begin{array}{l}\text { Study } \\
\text { Design }\end{array}$ & Condition & $\begin{array}{c}\text { Sample } \\
(N)\end{array}$ & Sex & Age (year) & Treatment (s) & Control & Duration & $\begin{array}{l}\text { Outcome } \\
\text { Measure }\end{array}$ & Results & $\begin{array}{c}\text { Effect } \\
\text { Summary }\end{array}$ \\
\hline $\begin{array}{l}\text { Cazaubiel \& } \\
\text { Desor [58] }\end{array}$ & RCT & $\begin{array}{l}\text { Mild anxiety (Hospital } \\
\text { Depression \& Anxiety } \\
\text { Scale (HADS) } \\
\text { score 4-12) }\end{array}$ & $\begin{array}{c}N=80 \\
\text { (Treatment } \\
n=40 ; \\
\text { Placebo } \\
n=40 \text { ) }\end{array}$ & 26M:54F & $\begin{array}{l}\text { Not } \\
\text { reported }\end{array}$ & $\begin{array}{l}\text { Fermented cow's milk } \\
\text { drink ( } 100 \mathrm{~mL}) \\
\text { containing milk } \\
\text { protein hydrolysate } \\
222 \mathrm{mg}+\mathrm{Mg} 48 \mathrm{mg} \\
\text { (Mg form unknown) }+ \\
\text { blackberry puree }\end{array}$ & Placebo & 4 weeks & $\begin{array}{l}\text { HADS } \\
\text { Symptom } \\
\text { Checklist } \\
\text { Cohen } \\
\text { Perceived } \\
\text { Stress Scale } \\
\text { Vitaliano } \\
\text { Coping } \\
\text { scale }\end{array}$ & $\begin{array}{l}\text { No significant difference between } \\
\text { treatment \& placebo on study outcome } \\
\text { measures. Post hoc analysis on restricted } \\
\text { data (HADS anxiety subscale score } 4-8, \\
\text { excluding scores } \geq 9) \text { revealed } \\
\text { significant decrease of } 31 \% \text { in treatment } \\
\text { group }(n=15) \text { vs. placebo }(n=16) \text { on the } \\
\text { anxiety sub-scale of the HADS }(p<0.05) \text {. }\end{array}$ & $+^{2}$ \\
\hline Gendle et al. [76] & RCT & $\begin{array}{c}\text { Subjective anxiety } \\
\text { (Westside Test Anxiety } \\
\text { Scale; normal anxiety; } \\
\text { elevated normal anxiety; } \\
\text { high anxiety; very } \\
\text { high anxiety) }\end{array}$ & $N=122$ & 31M:91F & $\begin{array}{l}x=19.3 \\
(\mathrm{SD}=1.17 \\
18-22)\end{array}$ & $\begin{array}{c}\mathrm{Mg} 300 \mathrm{mg} \text { as } \mathrm{Mg} \\
\text { citrate }\end{array}$ & $\begin{array}{l}\text { Placebo } \\
\text { (gelatin) }\end{array}$ & 5 days & $\begin{array}{l}\text { Spielberger } \\
\text { State-Trait } \\
\text { Anxiety } \\
\text { Inventory }\end{array}$ & $\begin{array}{l}\text { No significant difference between } \\
\text { treatment and placebo on pre-exam } \\
\text { anxiety rating. }\end{array}$ & $\mathrm{x}$ \\
\hline
\end{tabular}

${ }^{1}$ Total Score $>20$, with sum of 2 first items $<5$ \& score for item 6 (depressed mood) $<2{ }^{2}$ Post hoc analyses; ${ }^{*}$ No difference between treatments; Mg—Magnesium; mg-milligrams; VAS—visual analogue scale; + positive treatment effect; $x$ —no treatment effect; RCT—randomised controlled trial; Hospital Anxiety \& Depression Scale-HADS; SD—-standard deviation. 


\section{Summary of Effects of Mg in Anxious Samples}

Findings to date offer modest support that $\mathrm{Mg}$ intake confers benefits for individuals with pre-existing mild to moderate levels of anxiety. Four out of eight studies reported positive effects of $\mathrm{Mg}$ intake on anxiety outcomes. However, three studies are unpublished and one of these reports unreliable post hoc analyses in a significantly reduced subsample. Those studies which reported positive effects all administered $\mathrm{Mg}$ in combination with additional ingredients (e.g., vitamin $\mathrm{B}_{6}$, extract of Hawthorn and California poppy). None of the studies examined the effects of the included ingredients in isolation. Therefore, it is not possible to distinguish the relative contribution of each ingredient or confirm whether the positive effects observed are additive or synergistic. Three studies reported comparable efficacy between $\mathrm{Mg}$ and pharmaceutical anxiolytics. Whilst the strength of this evidence is diminished by a lack of a placebo comparator, it is indicative of the potential positive efficacy of $\mathrm{Mg}$. Non-inferiority in treatment effect of $\mathrm{Mg}$ supplementation compared to a proven, efficacious anxiolytic (e.g., Buspirone [83,84]) is suggestive of a promising role for $\mathrm{Mg}$ supplementation in the alleviation of subjective anxiety symptomology; especially considering the negative side effects associated with pharmaceutical anxiolytic intake and comparative safety of $\mathrm{Mg}$ supplementation. $\mathrm{Mg}$ All of the studies which included a placebo demonstrated significant placebo effects. Whilst positive effects of $\mathrm{Mg}$ were reported to be in excess of the effects of placebo, significant placebo effects suggest that any intervention in anxiety vulnerable samples may result in an amelioration of subjective anxiety complaints. The inclusion of an appropriate placebo to evaluate the effects of $\mathrm{Mg}$ interventions is therefore critical.

\subsection{Premenstrual Syndrome}

A summary of studies examining the effects of Mg intake in samples reporting PMS symptoms is shown in Table 2. Four of the seven studies recruiting samples based upon pre-existing PMS symptoms reported positive effects of $\mathrm{Mg}$ supplementation on anxiety outcomes. However, this positive evidence is undermined by a number of methodological limitations. De Souza et al. [67] administered $200 \mathrm{mg}$ $\mathrm{Mg}$ oxide alone and combined with vitamin $\mathrm{B}_{6}(50 \mathrm{mg})$ vs. vitamin $\mathrm{B}_{6}(50 \mathrm{mg})$ alone vs. a placebo for five consecutive menstrual cycles in a crossover manner. A significant reduction of anxiety-related premenstrual symptoms (nervous tension, mood swings, irritability, and anxiety) vs. baseline and placebo was reported after $200 \mathrm{mg} \mathrm{Mg}$ oxide + vitamin $\mathrm{B}_{6}(p=0.04)$. However, no overall treatment effects were found; the effect reported is the result of a priori planned treatment contrasts.

Quaranta et al. [85] administered $250 \mathrm{mg} \mathrm{Mg}$ in a modified release capsule for three menstrual cycles. Treatment significantly reduced total score on the Moos MDQ (including nervous tension and anxiety subscales; $p<0.001$ ), and on an anxiety subscale of a monthly PMS symptom diary $(p<0.001)$. However, these effects were relative to screening visit and baseline scores respectively. This study failed to administer any form of control or placebo. This is a methodological concern given evidence of the significant placebo effects previously discussed and demonstrated in PMS [86]. Indeed, Fathizadeh et al. [87] reported that $250 \mathrm{mg} \mathrm{Mg}$, alone and combined with vitamin $\mathrm{B}_{6}$, and a placebo, all resulted in a significant reduction in subjective PMS symptoms. Whilst the authors report that $250 \mathrm{mg} \mathrm{Mg}+$ vitamin $\mathrm{B}_{6}$ resulted in the greatest symptom amelioration $(p<0.05)$, these findings emphasise the robustness of the placebo effect in PMS samples and the need to evaluate active treatments against placebo treatments. The authors also analysed the effects of treatments on specific subjective PMS symptom subscales and reported a main effect of treatment on anxiety-related symptomology. However, appropriate follow up tests were not performed to distinguish between the treatment groups. 
Table 2. Summary of studies reporting the effects of $\mathrm{Mg}$ on subjective anxiety/stress in individuals reporting premenstrual syndrome symptoms.

\begin{tabular}{|c|c|c|c|c|c|c|c|c|c|c|}
\hline Author & $\begin{array}{c}\text { Study } \\
\text { Design }\end{array}$ & Condition & Sample (N) & Age (year) & $\begin{array}{l}\text { Treatment } \\
\text { (s) }\end{array}$ & Control & Duration & Outcome Measure & Results & $\begin{array}{c}\text { Effect } \\
\text { Summary }\end{array}$ \\
\hline $\begin{array}{c}\text { Facchinetti et al. } \\
\text { [88] }\end{array}$ & $\begin{array}{l}\text { RCT Cross } \\
\text { Placebo } \\
\text { Cross }\end{array}$ & $\begin{array}{l}\text { Premenstrual symptom } \\
\text { complaints Moos } \\
\text { Menstrual Distress } \\
\text { Questionnaire }(2 \\
\text { consecutive cycles } \\
\text { (DSM-IIIR criteria)) }\end{array}$ & $N=28$ & $\begin{array}{l}\text { Placebo: } \\
x=31.6 \\
\text { (SD = 5.9; } \\
24-39) ; \\
\text { Treatment: } \\
x=32.4 \\
\text { (SD =6.2; } \\
\text { 24-39) }\end{array}$ & $\begin{array}{l}\mathrm{Mg} 360 \mathrm{mg} \\
\text { as Mg } \\
\text { pyrrolidone } \\
\text { carboxylic } \\
\text { acid }\end{array}$ & Placebo & $\begin{array}{l}2 \text { months baseline }+4 \\
\text { menstrual cycles. } \\
\text { Treatment: } \mathrm{Mg} \times 22 \\
\text { cycles; placebo: } \\
\text { placebo } \times 2 \text { cycles }+ \\
\text { Mg } \times 2 \text { cycles (intake } \\
\text { during luteal } \\
\text { phases only) }\end{array}$ & $\begin{array}{l}\text { Moos Menstrual } \\
\text { Distress Questionnaire } \\
\text { (8 symptom categories: } \\
\text { pain, inability to } \\
\text { concentrate, autonomic } \\
\text { reactions, water } \\
\text { retention, negative } \\
\text { affect, arousal, } \\
\text { total score). }\end{array}$ & $\begin{array}{c}\text { Mg significantly reduced negative affect } \\
\text { ratings in the placebo crossover group } \\
(x=0.51(\mathrm{SD}=0.45)) \text { vs. placebo intake } \\
(x=0.76(\mathrm{SD}=0.70) ; p<0.05) \& \text { in the } \mathrm{Mg} \\
\text { treatment group after } 2(x=0.44 \\
(\mathrm{SD}=0.47)) \& 4(x=0.45(\mathrm{SD}=0.46)) \\
\text { cycles vs. baseline }(p<0.02) .\end{array}$ & + \\
\hline Walker et al. [89] & R-Cross & $\begin{array}{l}\text { Premenstrual symptom } \\
\text { complaints Menstrual } \\
\text { Health Questionnaire } \\
\text { (MHQ; retrospective } \\
\text { assessment of symptoms } \\
\text { during last cycle) }\end{array}$ & $N=38$ & $\begin{array}{c}18-50 \\
(71 \%-18-25 ; \\
7.9 \%-26-34 ; \\
13.2 \%-35-41 ; \\
7.9 \%-45-50)\end{array}$ & $\begin{array}{l}\mathrm{Mg} 200 \mathrm{mg} \\
\text { as Mg oxide }\end{array}$ & $\begin{array}{l}\text { Placebo } \\
\text { (cellulose) }\end{array}$ & $\begin{array}{l}4 \text { menstrual cycles }(2 \\
\text { cycles per treatment) }\end{array}$ & $\begin{array}{l}22 \text { item ordinal daily } \\
\text { menstrual symptom } \\
\text { diary (6 symptom } \\
\text { categories: anxiety; } \\
\text { cravings; hydration, } \\
\text { depression, other, total) }\end{array}$ & $\begin{array}{l}\text { No significant effect of treatment on } \\
\text { anxiety related premenstrual syndrome } \\
\text { symptoms. }\end{array}$ & $\mathrm{x}$ \\
\hline De Souza et al. [67] & R-Cross & $\begin{array}{l}\text { Premenstrual symptom } \\
\text { complaints Menstrual } \\
\text { Health Questionnaire } \\
\text { (MHQ; retrospective } \\
\text { assessment of previous } \\
\text { month and baseline) }\end{array}$ & $N=44$ & $x=32$ & $\begin{array}{l}\text { (i) } \mathrm{Mg} \\
200 \mathrm{mg} \text {; (ii) } \\
\text { vit } \mathrm{B} 650 \mathrm{mg} \text {; } \\
\text { (iii) Mg } \\
200 \mathrm{mg}+\text { vit } \\
\text { B6 } 50 \mathrm{mg} \text { (as } \\
\text { Mg oxide) }\end{array}$ & Placebo & $\begin{array}{l}5 \text { consecutive } \\
\text { menstrual cycles }\end{array}$ & $\begin{array}{l}30 \text { item ordinal daily } \\
\text { menstrual symptom } \\
\text { diary (6 symptom } \\
\text { categories: anxiety; } \\
\text { cravings; hydration, } \\
\text { depression, other, total) }\end{array}$ & $\begin{array}{l}\text { No overall treatment effect. Predefined } \\
\text { factorial treatment contrasts of adjusted } \\
\text { mean scores showed a significant effect of } \\
\text { Mg } 200 \mathrm{mg}+\text { vit } \mathrm{B}_{6} 50 \mathrm{mg}(x=16.3) \text { for } \\
\text { reducing anxiety related premenstrual } \\
\text { symptoms vs. baseline }(x=29.3) \& \\
\text { placebo }(x=19.8 ; p=0.04) \text { for one } \\
\text { menstrual cycle. }\end{array}$ & +1 \\
\hline Walker et al. [64] & R-Cross & $\begin{array}{l}\text { Premenstrual symptom } \\
\text { complaints Menstrual } \\
\text { Health Questionnaire } \\
\text { (MHQ; retrospective } \\
\text { assessment of previous } \\
\text { month and baseline) } \\
\end{array}$ & $N=85$ & $x=35$ & $\begin{array}{c}\text { (i) } \mathrm{Mg} \\
200 \mathrm{mg} \text {; (ii) } \\
\mathrm{Mg} 350 \mathrm{mg} ; \\
\text { (iii) Mg } \\
500 \mathrm{mg} \text { (all } \\
\text { as Mg oxide) }\end{array}$ & $\begin{array}{l}\text { Placebo } \\
\text { (sorbitol } \\
1305 \mathrm{mg})\end{array}$ & $\begin{array}{l}2 \text { menstrual cycles per } \\
\text { condition }\end{array}$ & $\begin{array}{l}20 \text { item ordinal daily } \\
\text { menstrual symptom } \\
\text { diary (6 6ymptom } \\
\text { categories: anxiety; } \\
\text { cravings; hydration, } \\
\text { depression, other, total) }\end{array}$ & $\begin{array}{c}\text { Significant reduction in anxiety-related } \\
\text { premenstrual symptoms after } 2 \text { months } \\
\text { placebo (sorbitol) intake }(x=1.7(\mathrm{SD}=2)) \\
\text { vs. } 200 \mathrm{mg}(x=3.6(\mathrm{SD}=2)), 350 \mathrm{mg} \\
(x=2.8(\mathrm{SD}=2)) \& 500 \mathrm{mg}(x=3.2 \\
(\mathrm{SD}=2)) \mathrm{Mg} \text { treatments. }\end{array}$ & $\mathrm{x}$ \\
\hline Khine et al. [63] & $\begin{array}{l}\text { P Post-hoc } \\
\text { R-Cross }\end{array}$ & $\begin{array}{l}\text { Premenstrual complaints } \\
\text { / Premenstrual Dysphoric } \\
\text { Disorder (PMDD) Daily } \\
\text { premenstrual symptoms } \\
\text { VAS ( } 3 \text { months) \& } \\
\text { retrospective DSM-IV } \\
\text { criteria for PMDD }\end{array}$ & $\begin{array}{l}N=31 \\
\text { (PMDD } n= \\
17 ; \text { Placebo } n \\
\quad=14 \text { ) }\end{array}$ & $\begin{array}{l}\text { Control: } \\
x=28.6 \\
\text { (SD }=6.4 ; \\
20-43) ; \\
\text { PMDD: } \\
x=37.4 \\
\text { (SD = 4.4; } \\
20-43)\end{array}$ & $\begin{array}{l}\text { Mg sulphate } \\
\text { intravenous } \\
\text { infusion } \\
0.1 \mathrm{mmol} / \mathrm{kg} \\
\text { body mass } \\
\text { (4h) }\end{array}$ & $\begin{array}{l}\text { Premenstrual } \\
\text { complaint-free } \\
\quad \text { controls }\end{array}$ & $24 \mathrm{~h}$ post infusion & $\begin{array}{l}\text { Spielberger State-Trait } \\
\text { Anxiety Inventory } \\
\text { Premenstrual Tension } \\
\text { Scale (Subjective \& } \\
\text { Objective) } 100 \mathrm{~mm} \\
\text { premenstrual symptom } \\
\text { VAS }\end{array}$ & $\begin{array}{l}\text { No significant mood changes in controls. } \\
\text { Evidence of improved VAS mood ratings } \\
\text { in initial } 6 \text { PMDD women after Mg } \\
\text { infusion resulted in post hoc initiated } \\
\text { RCT-cross with remaining } 10 \text { PMDD } \\
\text { women receiving Mg \& placebo infusion. } \\
\text { Mg infusion subsequently demonstrated } \\
\text { to have no mood improvement effects } \\
\text { above placebo. }\end{array}$ & $\mathrm{x}$ \\
\hline
\end{tabular}


Table 2. Cont.

\begin{tabular}{|c|c|c|c|c|c|c|c|c|c|c|}
\hline Author & $\begin{array}{c}\text { Study } \\
\text { Design }\end{array}$ & Condition & Sample (N) & Age (year) & $\begin{array}{l}\text { Treatment } \\
\text { (s) }\end{array}$ & Control & Duration & Outcome Measure & Results & $\begin{array}{c}\text { Effect } \\
\text { Summary }\end{array}$ \\
\hline Quaranta et al. [85] & NR-Cross & $\begin{array}{l}\text { Premenstrual symptom } \\
\text { complaints Moos } \\
\text { Modified Menstrual } \\
\text { Distress Questionnaire } \\
\text { (baseline score } \geq 25 \text { ) }\end{array}$ & $N=38$ & $\begin{array}{l}x=32.6 \\
(S D=8.0 \\
18-45)\end{array}$ & $\begin{array}{l}\text { Mg } 250 \mathrm{mg} \\
\text { (Mg form } \\
\text { unknown) }\end{array}$ & None & 3 menstrual cycles & $\begin{array}{l}\text { Moos Modified } \\
\text { Premenstrual Distress } \\
\text { Questionnaire } \\
\text { (including symptom } \\
\text { categories: nervous } \\
\text { tension, mood swings, } \\
\text { irritability, anxiety). } \\
\text { Monthly subjective } \\
\text { PMS symptom diary }\end{array}$ & $\begin{array}{l}\text { Moos Modified Menstrual Distress } \\
\text { Questionnaire: Total score: Significant } \\
\text { reduction after } 3 \text { months }(x=19.7 \\
(\mathrm{SD}=7.6)) \text { vs. screening visit }(x=30.5 \\
(\mathrm{SD}=4.5) ; p<0.001) \text {. Monthly subjective } \\
\text { PMS symptom diary: Total score: } \\
\text { Significant reduction at month } 1(x=23.3 \\
(\mathrm{SD}=10.6)) \text {, month } 2(x=19.6(\mathrm{SD}=7.8)), \\
\& \text { month } 3(x=17.9(\mathrm{SD}=7.3)) \text { with } \\
\text { treatment vs. baseline months } 1(x=31.8 \\
(\mathrm{SD}=6.4)) \& 2(x=31.3(\mathrm{SD}=8.4) ; \\
p<0.001) \text {. PMS anxiety subscale: } \\
\text { Significant decrease in anxiety subscale } \\
\text { ratings at month } 1(x=6.3), \text { month } 2 \\
(x=5.3), \& \text { month } 3(x=5.0) \text { with } \\
\text { treatment vs. baseline }(x=8.4 ; p<0.001) .\end{array}$ & + \\
\hline $\begin{array}{c}\text { Fathizadeh et al. } \\
\text { [87] }\end{array}$ & RCT & $\begin{array}{l}\text { Premenstrual symptom } \\
\text { complaints Daily } \\
\text { premenstrual symptoms } \\
\text { record (2 months) }\end{array}$ & $\begin{array}{c}\mathrm{N}=116 \\
\text { (Treatments } \\
\text { (i) } n=38 ; \text { (ii) } \\
n=41 ; \\
\text { Placebo } \\
n=37 \text { ) }\end{array}$ & $\begin{array}{l}\text { Placebo: } \\
x=28.03 ; \\
\text { Treatment } \\
\text { (i): } x=28.71 ; \\
\text { Treatment; } \\
\text { (ii): } x=30.02 \\
\text { (all 15-45) }\end{array}$ & $\begin{array}{l}\text { (i) Mg } \\
250 \mathrm{mg} \text {; (ii) } \\
\mathrm{Mg} 250 \mathrm{mg}+ \\
\text { vit } \mathrm{B}_{6} 40 \mathrm{mg} \\
\text { (Mg form } \\
\text { unknown) }\end{array}$ & Placebo & 2 months & $\begin{array}{l}\text { Daily menstrual } \\
\text { symptom diary (6 } \\
\text { symptom categories: } \\
\text { anxiety, cravings, } \\
\text { hydration, depression, } \\
\text { somatic, total) }\end{array}$ & $\begin{array}{c}\text { Significant reduction in total PMS } \\
\text { symptoms in all conditions. Mg }+ \text { vit B6 } \\
\text { resulted in greatest reduction }(p<0.05) \text {. } \\
\text { Significant main effect of treatments on } \\
\text { change from baseline anxiety ratings } \\
\left(\mathrm{Mg}+\text { vit } \mathrm{B}_{6}: x=-22.61(\mathrm{SD}=20.36) ; \mathrm{Mg}:\right. \\
x=-12.14 \text { : } \mathrm{SD}=26.14) ; \text { placebo: } x=0 \\
(\mathrm{SD}=20.41) ; p<0.001) \text {. However, no } \\
\text { between treatment planned contrasts or } \\
\text { post-hoc tests reported. }\end{array}$ & $+?$ \\
\hline
\end{tabular}

${ }^{1}$ Post hoc analyses; Mg—Magnesium; mg—milligrams; PMDD—Premenstrual Dysphoric Disorder; PMS—-premenstrual syndrome; VAS—visual analogue scale; MHQ—Menstrual Health Questionnaire; + positive treatment effect; $x$ no treatment effect; ? — doubts about outcome; RCT—randomised controlled trial; P-parallel groups; R-Cross—randomised crossover; NR-Cross-non-randomised crossover; $\mathrm{B}_{6}$ - vitamin $\mathrm{B}_{6} ; \mathrm{SD}$ - standard deviation. 
The final study reporting positive effects of $\mathrm{Mg}$ administered $360 \mathrm{mg}$ pyrrolidone carboxylic acid $\mathrm{Mg}$ vs. placebo [88]. Magnesium intake significantly reduced subjective premenstrual negative affect symptoms on the Moos MDQ, which includes the symptoms anxiety and tension [66]. This effect of $\mathrm{Mg}$ was shown in a placebo/treatment crossover condition (2 months placebo intake vs. 2 months $\mathrm{Mg}$ intake; $p<0.05$ ), and after 2 and 4 months intake (vs. baseline) in a Mg treatment condition $(p<0.05)$.

Three studies reported no effects of Mg intake on anxiety-related PMS symptoms. Walker et al. [89] found no effects of 2 months administration of $200 \mathrm{mg} \mathrm{Mg}$ oxide on PMS symptomology. A further study by this group examined potential $\mathrm{Mg}$ dose-response effects by administering 200, 350, and $500 \mathrm{mg}$ $\mathrm{Mg}$ oxide in a placebo controlled crossover trial [64]. Placebo intake (1305 mg sorbitol) significantly reduced subjective total and anxiety-related PMS symptoms after 2 months compared to all doses of $\mathrm{Mg}(p<0.001)$. The authors suggest the positive effects of sorbitol may be due to the raising of depleted intracellular sorbitol concentrations caused by hypoglycaemia, which is a suggested-though unconfirmed-symptom of PMS. Therefore, the effect of sorbitol may be specific to the PMS sample. Indeed, the authors additionally demonstrated that sorbitol reduced urinary Mg excretion in PMS (vs. baseline and $\mathrm{Mg}$ treatments), but not asymptomatic controls (vs. baseline and cellulose placebo). The dose and duration of intake may also be relevant since effects were not evident after one month, and the Mg treatments contained smaller doses of sorbitol (Mg $200 \mathrm{mg}=1050 \mathrm{mg}$; $350 \mathrm{mg}=830 \mathrm{mg}$; $500 \mathrm{mg}=717 \mathrm{mg}$ sorbitol). It is not possible to discern the extent to which this finding is of relevance to other PMS studies reporting placebo effects as the nature of the placebo has rarely been detailed. Only Walker et al. [89] report the form of placebo administered (cellulose). Therefore, the potential impact of placebo content on the effects observed in PMS symptom samples is not known.

In a methodologically flawed study, Khine et al. [63] initially adopted a parallel groups design comparing women reporting PMS complaints or meeting the criteria for premenstrual dysphoric disorder (PMDD) with non PMS controls. The authors administered $0.1 \mathrm{mmol} / \mathrm{kg}$ body mass of $\mathrm{Mg}$ sulphate via intravenous infusion over four hours. The acute subjective effects of $\mathrm{Mg}$ infusion were assessed $24 \mathrm{~h}$ later by the STAI, the Premenstrual Tension Scale [90] and a PMS symptom VAS. The study design was altered mid-testing after improved VAS mood ratings were reported in the PMS/PMDD participants only $(n=6)$. The Mg and a placebo infusion were subsequently administered to 10 more PMS/PMDD women in a crossover manner. No significant differences between $\mathrm{Mg}$ and placebo were demonstrated on any subjective outcomes in this subsequently combined sample. Moreover, any outcomes are crucially compromised due to the decision to alter the study design based upon emerging data.

The heterogeneity in the evidence for the efficacy of $\mathrm{Mg}$ in treatment of anxiety-related PMS symptoms may be explained by the divergent methods employed to characterise PMS samples. For example, four studies $[64,67,85,89]$ employed retrospective assessment of PMS symptoms over the previous month and/or at baseline. The reliance on retrospective diagnosis has been criticized [91] since these often result in inflated estimates of symptom severity [92]. Only Facchinetti et al. [88] report the assessment of daily PMS symptoms in the 2 months prior to study commencement to identify eligibility (according to DSM-IIIR criteria). Khine et al. [63] and Fathizadeh et al. [87] also collected daily symptom records in the months ( 3 and 2 months respectively) prior to study commencement. However, not enough detail is reported to determine by which criteria participant eligibility was ascertained. Therefore, it is not easy to assess the equivalency of PMS symptom severity across the samples. This is problematic if, for example, the potential functional effects of $\mathrm{Mg}$ supplementation operate as a function of PMS symptom severity (e.g., attenuating symptoms in mild or very severe cases). A more consistent approach to assessing PMS symptomology prior to inclusion may reduce some of the variability evident in the existing literature.

\section{Summary of Effects of Mg in PMS Samples}

The findings to date suggest a potential positive role for $\mathrm{Mg}$ supplementation on subjective anxiety in women reporting PMS symptoms. Positive effects of Mg were reported both in isolation 
and when combined with vitamin $\mathrm{B}_{6}$. Studies reporting positive effects of $\mathrm{Mg}$ combined with vitamin $\mathrm{B}_{6}$ demonstrated effects superior to those of $\mathrm{Mg}$ administered alone. However, evidence of the effects of Mg intake on subjective PMS related anxiety are undermined by a number of methodological issues. A lack, or inappropriate application, of a placebo control, and design and analysis issues all contribute to the ability to draw clear conclusions as regards this problem. Careful selection of an appropriate placebo control for samples of this nature (sub-clinical complaints) is also highlighted by the apparent specific functional effects of sorbitol on women with PMS. A more consistent approach to diagnosis (preferably using DSM-IV criteria and characterising PMS samples is required to permit better assessment of the equivalency of PMS symptom severity and response to treatment between studies.

\subsection{Postpartum Anxiety}

One study examined the capacity of $\mathrm{Mg}$ intake to ameliorate postpartum $(\leq 48 \mathrm{~h})$ anxiety in a healthy sample (Table 3). No significant effects on subjective anxiety rating (STAI) in the eight weeks following child birth were recorded following daily supplementation with $64.4 \mathrm{mg} \mathrm{Mg}$ (vs. placebo and zinc; [68]).

Summary of Effects of Mg in Postpartum

There is currently no evidence to support the efficacy of $\mathrm{Mg}$ intake in the reduction of postpartum subjective anxiety.

\subsection{Mild Hypertension}

A summary of studies examining the effects of $\mathrm{Mg}$ intake in mild hypertensive samples is shown in Table 4. Both studies employed general subjective measures of quality of life (QoL) and well-being which comprised subscales related to stress and anxiety. Therefore, the findings are considered to contribute only modest evidence to support the examination of the efficacy of $\mathrm{Mg}$ intake on anxiety/stress. Borrello et al. [70] administered $200 \mathrm{mg} \mathrm{Mg}$ oxide vs. placebo for 12 weeks in a hypertensive sample. Magnesium intake resulted in significantly higher QoL ratings (inclusive of scales measuring subjective emotional behaviour and concerns about the future) vs. placebo and baseline at 12 weeks $(p<0.05)$. Conversely, Walker et al. [69] found no effects of 10 weeks intake of $600 \mathrm{mg} \mathrm{Mg}$ chelate on a subjective well-being measure (comprising an anxiety subscale) when administered in isolation or in combination with Hawthorn extract $(500 \mathrm{mg})$.

\section{Summary of Effects of Mg in Hypertensive Samples}

Evidence of specific anxiety/stress reducing effects of $\mathrm{Mg}$ intake in hypertensive individuals is weak due to the inconsistency of evidence and failure to employ specific subjective anxiety/stress outcome measures. However, the capacity for $\mathrm{Mg}$ intake to affect subjective indices of mood (QoL) suggests further examination of the efficacy of $\mathrm{Mg}$ in hypertensive samples is warranted. Evaluating the efficacy of $\mathrm{Mg}$ on subjective anxiety in samples with clinical conditions is complicated by the underlying clinical complaint. For example, an improvement in subjective anxiety may be as a result of an improvement in the clinical symptomology rather than a direct effect of $\mathrm{Mg}$ on anxiety. However, this is contradicted by the current available evidence as both studies in hypertensive samples demonstrated $\mathrm{Mg}$ reduced blood pressure responses but did not affect subjective anxiety levels. 
Table 3. Summary of studies reporting the effects of $\mathrm{Mg}$ on subjective anxiety/stress in postpartum women.

\begin{tabular}{|c|c|c|c|c|c|c|c|c|c|c|c|}
\hline Author & $\begin{array}{c}\text { Study } \\
\text { Design }\end{array}$ & Condition & Sample $(N)$ & Sex & Age (year) & Treatment (s) & Control & Duration & $\begin{array}{l}\text { Outcome } \\
\text { Measure }\end{array}$ & Results & $\begin{array}{c}\text { Effect } \\
\text { Summary }\end{array}$ \\
\hline Fard et al. [68] & RCT & $\begin{array}{l}\text { Postpartum } \\
\leq 48 \mathrm{~h}\end{array}$ & $\begin{array}{l}N=95 \text { (Treatments: } \\
\text { (i) } n=31 ; \text { (ii) } n=31 \text {; } \\
\text { Placebo: } n=33 ;\end{array}$ & $\mathrm{F}$ & $\begin{array}{l}\text { Treatments: (i) } x=29.4 \\
(\mathrm{SD}=5.4) ;(\mathrm{ii}) x=26.4 \\
(\mathrm{SD}=4.8) ; \text { Placebo } \\
x=27.6(\mathrm{SD}=5.1)\end{array}$ & $\begin{array}{l}\text { (i) Zinc sulphate } \\
27 \mathrm{mg}(11 \mathrm{mg} \\
\text { elemental zinc); (ii) } \\
\text { Mg sulphate } 320 \mathrm{mg} \\
\text { (64.6 elemental Mg) }\end{array}$ & $\begin{array}{c}\text { Placebo } \\
\text { (lactose, starch, } \\
\text { cellulose, } \mathrm{Mg} \\
\text { stearate) }\end{array}$ & 8 weeks & $\begin{array}{c}\text { Spielberger } \\
\text { State-Trait } \\
\text { Anxiety } \\
\text { Inventory }\end{array}$ & $\begin{array}{c}\text { No } \\
\text { significant } \\
\text { differences } \\
\text { between } \\
\text { treatments }\end{array}$ & $x$ \\
\hline
\end{tabular}

$\mathrm{Mg}$-Magnesium; mg—-milligrams; + positive treatment effect; - negative treatment effect; $x$ no treatment effect; RCT—randomised controlled trial.

Table 4. Summary of studies reporting the effects of $\mathrm{Mg}$ on subjective anxiety/stress in individuals with mild to moderate hypertension.

\begin{tabular}{|c|c|c|c|c|c|c|c|c|c|c|c|}
\hline Author & $\begin{array}{c}\text { Study } \\
\text { Design }\end{array}$ & Condition & $\begin{array}{c}\text { Sample } \\
(N)\end{array}$ & Sex & Age (year) & Treatment (s) & Control & Duration & Outcome Measure & Results & $\begin{array}{c}\text { Effect } \\
\text { Summary }\end{array}$ \\
\hline Borrello et al. [70] & RCT & $\begin{array}{c}\text { Mild } \\
\text { hypertension } \\
\text { (Diastolic } \\
\text { BP > } 90 \mathrm{mmHg} \\
\text { or Systolic BP } \\
>140 \mathrm{mmHg} \text { ) }\end{array}$ & $\begin{array}{c}N=83 \\
\text { (Treatment } \\
n=42 ; \\
\text { Placebo } \\
n=41 \text { ) }\end{array}$ & 30M:53F & $\begin{array}{c}\text { Placebo: } x=49 \\
\text { Treatment: } x=51\end{array}$ & Mg oxide $200 \mathrm{mg}$ & Placebo & 12 weeks & $\begin{array}{l}44 \text { item Quality of } \\
\text { Life Likert } \\
\text { questionnaire } \\
\text { (subscales: } \\
\text { emotional behaviour } \\
\text { \& concerns about } \\
\text { the future) }\end{array}$ & $\begin{array}{c}\text { Significantly higher } \\
\text { total quality of life } \\
\text { rating after } 12 \text { weeks } \\
\text { treatment }(x=67.58 \\
(\mathrm{SD}=5)) \text { vs. baseline } \\
(x=73.58(\mathrm{SD}=6)) \& \\
\text { placebo }(x=73.23 \\
(\mathrm{SD}=8) ; p<0.05) .\end{array}$ & + \\
\hline Walker et al. [64] & RCT & $\begin{array}{c}\text { Mild } \\
\text { hypertension } \\
\text { (Diastolic BP } \\
85-100 \mathrm{mmHg} \text { ) }\end{array}$ & $\begin{array}{c}N=36(9 \\
\text { per } \\
\text { condition) }\end{array}$ & $18 \mathrm{M}: 18 \mathrm{~F}$ & $\begin{array}{c}\text { Placebo: } x=49 ; \\
\text { Treatment (i): } \\
x=53.2 ; \text { Treatment } \\
\text { (ii): } x=53 \text {; } \\
\text { Treatment (iii): } \\
x=48.8\end{array}$ & $\begin{array}{c}\text { (i) Mg amino acid } \\
\text { chelate (600 mg } \\
\text { elemental Mg/day); } \\
\text { (ii) Hawthorn extract } \\
500 \mathrm{mg} \text {; (iii) (i) + (ii) } \\
\text { combined }\end{array}$ & $\begin{array}{l}\text { Placebo } \\
\text { (cellulose) }\end{array}$ & 10 weeks & $\begin{array}{c}\text { Subjective } \\
\text { well-being } \\
\text { questionnaire } \\
\text { (subscales: vitality, } \\
\text { anxiety \& } \\
\text { depression) }\end{array}$ & $\begin{array}{l}\text { No significant effects } \\
\text { on subjective } \\
\text { well-being. }\end{array}$ & $\mathrm{x}$ \\
\hline
\end{tabular}

$\mathrm{Mg}$-Magnesium; mg—-milligrams; + positive treatment effect; - negative treatment effect; $\mathrm{x}$ no treatment effect; RCT—randomised controlled trial. 


\subsection{Moderating Variables}

\subsubsection{Dosage and Differential Bioavailability of Mg Forms}

No clear dose effect of $\mathrm{Mg}$ emerges from the reviewed studies. Positive effects of $\mathrm{Mg}$ intake on subjective anxiety outcomes are reported with both low (75 mg [72]) and higher (360 mg [88]) Mg doses. One study that systematically examined the potential dosing effects of $\mathrm{Mg}$ (administering 200, 350, and $500 \mathrm{mg}$ ) reported no effects of any dose [64]. Examination of the effect of $\mathrm{Mg}$ dose is further complicated by a number of the studies reporting positive outcomes combining $\mathrm{Mg}$ with additional ingredients (e.g., Hawthorn extract [72]). Therefore, it is difficult to assess if it is $\mathrm{Mg}$ administered at a particular dose that is efficacious, or the additional ingredients acting in isolation or synergistically with Mg.

An additional factor that needs to be acknowledged is the variable bioavailability of different $\mathrm{Mg}$ forms. Magnesium chloride, sulphate, citrate, lactate, malate, glycinate and taurinate are highly biologically available whilst Mg oxide appears to be significantly less bioavailable [93-95]. However, there is no consistent moderating effect of $\mathrm{Mg}$ form on reported anxiety outcomes. Four studies administered Mg oxide [64,67,70,89]. Two studies reported positive effects of Mg oxide intake, however, positive effects were observed only when combined with vitamin $B_{6}[67]$ and on a subjective general well-being questionnaire including anxiety-related factors rather than specific measures of anxiety [70]. Two of five studies administering $\mathrm{Mg}$ lactate reported positive effects of this $\mathrm{Mg}$ form. One study reported pyrrolidone carboxylic acid reduced subjective negative affect. Conversely, no effects of citrate, sulphate (intravenous) or amino acid chelate $\mathrm{Mg}$ forms have been demonstrated. Therefore, whilst the bioavailability of $\mathrm{Mg}$ forms should be considered when planning an intervention, the current available evidence is not sufficient to determine the relative efficacy of specific $\mathrm{Mg}$ forms in the attenuation of subjective anxiety outcomes.

\subsubsection{Duration of Intake}

The majority of the existing evidence of the positive effects is from studies administering $\mathrm{Mg}$ for 6-12 weeks. However, this is also true for studies reporting no effects of $\mathrm{Mg}$. Hence, intervention length may not be the principal moderating variable contributing to the heterogeneous effects. There is a paucity of research assessing the acute effects of Mg intake in humans. Gendle et al. [76] reported no effects after 5 days but the sample and anxiety context were markedly different to those sub-clinical and chronically anxious samples recruited in studies reporting positive effects of Mg. Khine et al. [63] reported no effect of an acute intravenous $\mathrm{Mg}$ dose but methodological flaws in this study undermine interpretation of the findings.

\subsection{3. $\mathrm{Mg}$ Status}

The majority of studies summarised cite the observed relationship between $\mathrm{Mg}$ depletion and affective states as a rationale to hypothesise a potential positive effect of $\mathrm{Mg}$ supplementation on subjective anxiety. The exclusive selection of anxiety vulnerable samples (e.g., moderately anxious, PMS symptomology) is based on an assumption that the positive effects of Mg supplementation are more likely observed in those that are compromised or depleted in some way. However, none of the reported studies specifically recruited samples depleted in $\mathrm{Mg}$ to assess the effect of $\mathrm{Mg}$ intake. A number of studies measured urinary and/or serum $\mathrm{Mg}$ status at baseline and over the course/at the completion of the study. These measures were recorded only to confirm the equivalence of treatment groups at baseline and increased $\mathrm{Mg}$ bioavailability in $\mathrm{Mg}$ conditions or protocol compliance. No attempt was made to incorporate basal Mg status in the statistical analyses of Mg outcomes.

\section{Conclusions and Research Recommendations}

In conclusion, there is suggestive but inconclusive evidence for a beneficial effect of $\mathrm{Mg}$ supplementation in mild anxiety. Similarly the evidence from studies of women who complain 
of premenstrual symptoms also suggests that $\mathrm{Mg}$ could confer benefits. In both cases this is based on a reasonable number of studies which have used appropriate measures of symptoms. However, the weaknesses in the designs highlighted and the substantial placebo response noted in most studies preclude strong recommendations for $\mathrm{Mg}$ as a treatment option at this stage. The evidence for $\mathrm{Mg}$ in hypertension is based on only two studies, both of which do not measure specific symptoms but generic quality of life indices which are unlikely to detect changes in underlying specific symptoms.

The quality of studies was generally poor. Studies that included a placebo condition often failed to evaluate effects appropriately. Studies were marred by inappropriate selection of samples, failure to confirm diagnosis, lack of placebo controls, and weak statistical analysis. It is clear therefore that well-designed randomised controlled trials are required. Such trials should include careful screening of samples and confirmation of the presence of anxiety at levels where a treatment effect would be noticeable (e.g., mild, moderate) on measures with sufficient range. The specific examination of $\mathrm{Mg}$ efficacy in individuals with lowered $\mathrm{Mg}$ resources is also recommended considering the evidence of the relationship between the depleted state and affective pathologies. The inclusion of a placebo control (with documented content) is crucial as is appropriate power to detect treatment effects and an appropriate statistical analysis strategy, which includes consideration of baseline symptoms as a covariate rather than relative to screening along with planned comparisons against the placebo treatment. Longer term studies should also consider the inclusion of a placebo run-in, whilst acknowledging that placebo response can be quite prolonged in studies of subjective symptoms such as anxiety or PMS. The lack of significant differences between proven anxiolytic pharmaceuticals and $\mathrm{Mg}$ intake in the alleviation of subjective stress ratings suggests study designs may also benefit from the inclusion of a positive verum. This would permit a fair assessment of the efficacy of $\mathrm{Mg}$.

The effects of $\mathrm{Mg}$ on clinical affective disorders and experimental studies of anxiety in animal models provide a clear rationale to propose that $\mathrm{Mg}$ supplementation will have a beneficial effect on mild/moderate anxiety. There is also sufficient potential mechanistic pathways via which $\mathrm{Mg}$ could modulate affective states. It is the quality of the available evidence rather than the absence of a potential mechanism which has hindered convincing demonstration of such effects.

The potential effect of $\mathrm{Mg}$ in attenuating psychological response to stress merits further investigation since stress is a ubiquitous feature of modern lives. The modulation of the HPA axis by $\mathrm{Mg}$, which has been demonstrated to reduce central (ACTH; [15]) and peripheral (cortisol; [49]) endocrine responses, suggests that behavioural effects of stress exposure such as anxiety could be attenuated by Mg supplementation.

Acknowledgments: The authors N.B. and C.L. received funding from Sanofi to conduct the initial systematic publication database search of the effects of $\mathrm{Mg}$ on subjective stress and anxiety. Sanofi also provided access to data from 3 unpublished $\mathrm{Mg}$ intervention studies.

Author Contributions: N.B. and C.L. conducted the systematic database and grey literature search. N.B., C.L. and L.D. contributed equally to the writing of the review.

Conflicts of Interest: N.B. and C.L. declare no conflict of interest. L.D. is currently a member of the Sanofi Consumer Healthcare Advisory Board. Sanofi had no role in the collection, review or interpretation of data; in the writing of the manuscript, and in the decision to publish the review.

\section{Appendix A}

Grey Literature Search Resources

PsychExtra: www.apa.org/pubs/databases/psycextra/

Open Grey: www.opengrey.eu/

Google Scholar (first 1000 returns per search): https:/ /scholar.google.co.uk/

TRIP database: https://www.tripdatabase.com/

Information for Practice: http://ifp.nyu.edu/

Grey Literature Report: http:/ /www.greylit.org/

Latin American Open Archives Portal: http://lanic.utexas.edu/project/laoap/ 
British Library EThOS eThesis online service: http:/ / ethos.bl.uk/Home.do National Institute for Health Research (INVOLVE): http:/ /www.invo.org.uk/

The OAlster Database: www.oclc.org/oaister.en.html

Health Management Information Consortium: www.lshtm.ac.uk/library/resources/databases/ info_hmic.html

UK Department of Health: www.gov.uk/government/organisations/department-of-health

Centers for Disease Control and Prevention: www.cdc.gov

National Institute of Health: www.nih.gov

World Health Organization: www.who.int/en/

European Food Safety Authority: www.efsa.europa.eu

\section{References}

1. Swaminathan, R. Magnesium metabolism and its disorders. Clin. Biochem. Rev. 2003, 242, 47-66.

2. Topf, J.M.; Murray, P.T. Hypomagnesemia and hypermagnesemia. Rev. Endocr. Metab. Disord. 2003, 42, 195-206. [CrossRef]

3. King, D.E.; Mainous, A.G., 3rd; Geesey, M.E.; Woolson, R.F. Dietary magnesium and C-reactive protein levels. J. Am. Coll. Nutr. 2005, 243, 166-171.

4. Ford, E.S.; Mokdad, A.H. Dietary magnesium intake in a national sample of US adults. J. Nutr. 2003, 1339, 2879-2882.

5. Dolega-Cieszkowski, J.H.; Bobyn, J.P.; Whiting, S.J. Dietary intakes of Canadians in the 1990s using population-weighted data derived from the provincial nutrition surveys. Appl. Physiol. Nutr. Metab. 2006, 316, 753-758. [CrossRef] [PubMed]

6. Galan, P.; Preziosi, P.; Durlach, V.; Valeix, P.; Ribas, L.; Bouzid, D.; Favier, A.; Hercberg, S. Dietary magnesium intake in a French adult population. Magnes. Res. 1997, 104, 321-328.

7. Song, Y.; Sesso, H.D.; Manson, J.E.; Cook, N.R.; Buring, J.E.; Liu, S. Dietary magnesium intake and risk of incident hypertension among middle-aged and older US women in a 10-year follow-up study. Am. J. Cardiol. 2006, 9812, 1616-1621. [CrossRef] [PubMed]

8. Song, Y.Q.; Manson, J.E.; Cook, N.R.; Albert, C.M.; Buring, J.E.; Liu, S. Dietary magnesium intake and risk of cardiovascular disease among women. Am. J. Cardiol. 2005, 968, 1135-1141. [CrossRef] [PubMed]

9. Song, Y.Q.; Manson, J.E.; Buring, J.E.; Liu, S. Dietary magnesium intake in relation to plasma insulin levels and risk of type 2 diabetes in women. Diabetes Care 2004, 271, 59-65. [CrossRef]

10. Derom, M.L.; Sayón-Orea, C.; Martínez-Ortega, J.M.; Martínez-González, M.A. Magnesium and depression: A systematic review. Nutr. Neurosci. 2013, 165, 191-206. [CrossRef] [PubMed]

11. Eby, G.A., III; Eby, K.L. Magnesium for treatment-resistant depression: A review and hypothesis. Med. Hypotheses 2010, 744, 649-660. [CrossRef] [PubMed]

12. Murck, H. Magnesium and affective disorders. Nutr. Neurosci. 2002, 56, 375-389. [CrossRef] [PubMed]

13. Hallak, M.; Berman, R.F.; Irtenkauf, S.M.; Evans, M.I.; Cotton, D.B. Peripheral Magnesium-Sulfate Enters the Brain and Increases the Threshold for Hippocampal Seizures in Rats. Am. J. Obstet. Gynecol. 1992, 1676, 1605-1610. [CrossRef]

14. Cotton, D.B.; Hallak, M.; Janusz, C.; Irtenkauf, S.M.; Berman, R.F. Central Anticonvulsant Effects of Magnesium-Sulfate on N-Methyl-D-Aspartate Induced Seizures. Am. J. Obstet. Gynecol. 1993, 1683, 974-978. [CrossRef]

15. Murck, H.; Steiger, A. Mg2+ reduces ACTH secretion and enhances spindle power without changing delta power during sleep in men-Possible therapeutic implications. Psychopharmacology 1998, 1373, 247-252. [CrossRef]

16. Glynn, P.; Cooper, D.M.F.; Schulster, D. Modulation of Response of Bovine Adrenocortical Adenylate-Cyclase to Corticotropin. Biochem. J. 1977, 1682, 277-282. [CrossRef]

17. Ueda, K.; Okamura, N.; Hirai, M.; Tanigawara, Y.; Saeki, T.; Kioka, N.; Komano, T.; Hori, R. Human p-glycoprotein transports cortisol, aldosterone, and dexamethasone, but not progesterone. J. Biol. Chem. $1992,26734,24248-24252$. 
18. Karssen, A.M.; Meijer, O.C.; van der Sandt, I.C.; Lucassen, P.J.; de Lange, E.C.; de Boer, A.G.; de Kloet, E.R. Multidrug resistance P-glycoprotein hampers the access of cortisol but not of corticosterone to mouse and human brain. Endocrinology 2001, 1426, 2686-2694. [CrossRef] [PubMed]

19. Hamada, H.; Tsuruo, T. Characterization of the atpase activity of the mr 170,000 to 180,000 membrane glycoprotein (p-glycoprotein) associated with multidrug resistance in k562/adm cells. Cancer Res. 1988, 4817, 4926-4932.

20. Muroyama, A.; Inaka, M.; Matsushima, H.; Sugino, H.; Marunaka, Y.; Mitsumoto, Y. Enhanced susceptibility to MPTP neurotoxicity in magnesium-deficient C57BL/6N mice. Neurosci. Res. 2009, 631, 72-75. [CrossRef] [PubMed]

21. Singewald, N.; Sinner, C.; Hetzenauer, A.; Sartori, S.B.; Murck, H. Magnesium-deficient diet alters depressionand anxiety-related behavior in mice-Influence of desipramine and Hypericum perforatum extract. Neuropharmacology 2004, 478, 1189-1197. [CrossRef] [PubMed]

22. Spasov, A.A.; Iezhitsa, I.N.; Kharitonova, M.V.; Kravchenko, M.S. Depression-like and anxiety-related behaviour of rats fed with magnesium-deficient diet. Zhurnal Vysshei Nervnoi Deyatelnosti Imeni I P Pavlova 2008, 584, 476-485.

23. Whittle, N.; Li, L.; Chen, W.Q.; Yang, J.W.; Sartori, S.B.; Lubec, G.; Singewald, N. Changes in brain protein expression are linked to magnesium restriction-induced depression-like behavior. Amino Acids 2011, 404, 1231-1248. [CrossRef] [PubMed]

24. Jacka, F.N.; Overland, S.; Stewart, R.; Tell, G.S.; Bjelland, I.; Mykletun, A. Association between magnesium intake and depression and anxiety in community-dwelling adults: The Hordaland Health Study. Aust. N. Z. J. Psychiatry 2009, 431, 45-52. [CrossRef] [PubMed]

25. Hashizume, N.; Mori, M. An analysis of hypermagnesemia and hypomagnesemia. Jpn. J. Med. 1990, 294, 368-372. [CrossRef]

26. Banki, C.M.; Vojnik, M.; Papp, Z.; Balla, K.Z.; Arató, M. Cerebrospinal-fluid magnesium and calcium related to amine metabolites, diagnosis, and suicide attempts. Biol. Psychiatry 1985, 202, 163-171. [CrossRef]

27. Bjorum, N. Electrolytes in blood in endogenous depression. Acta Psychiatr. Scand. 1972, 481, 59-68. [CrossRef]

28. Cade, J.F. A Significant Elevation of Plasma Magnesium Levels in Schizophrenia and Depressive States. Med. J. Aust. 1964, 1, 195-196. [PubMed]

29. Widmer, J.; Bovier, P.; Karege, F.; Raffin, Y.; Hilleret, H.; Gaillard, J.M.; Tissot, R. Evolution of Blood Magnesium, Sodium and Potassium in Depressed-Patients Followed for 3 Months. Neuropsychobiology 1992, 264, 173-179. [CrossRef]

30. Poleszak, E.; Szewczyk, B.; Kedzierska, E.; Wlaź, P.; Pilc, A.; Nowak, G. Antidepressant- and anxiolytic-like activity of magnesium in mice. Pharmacol. Biochem. Behav. 2004, 78, 7-12. [CrossRef] [PubMed]

31. Cardoso, C.C.; Lobato, K.R.; Binfaré, R.W.; Ferreira, P.K.; Rosa, A.O.; Santos, A.R.; Rodrigues, A.L. Evidence for the involvement of the monoaminergic system in the antidepressant-like effect of magnesium. Prog. Neuropsychopharmacol. Biol. Psychiatry 2009, 332, 235-242. [CrossRef] [PubMed]

32. Fromm, L.; Heath, D.L.; Vink, R.; Nimmo, A.J. Magnesium attenuates post-traumatic depression/anxiety following diffuse traumatic brain injury in rats. J. Am. Coll. Nutr. 2004, 23, 529S-533S. [CrossRef] [PubMed]

33. Barragan-Rodriguez, L.; Rodriguez-Moran, M.; Guerrero-Romero, F. Depressive symptoms and hypomagnesemia in older diabetic subjects. Arch. Med. Res. 2007, 387, 752-756. [CrossRef] [PubMed]

34. Eby, G.A.; Eby, K.L. Rapid recovery from major depression using magnesium treatment. Med. Hypotheses 2006, 672, 362-370. [CrossRef] [PubMed]

35. Enya, M.; Kanoh, Y.; Mune, T.; Ishizawa, M.; Sarui, H.; Yamamoto, M.; Takeda, N.; Yasuda, K.; Yasujima, M.; Tsutaya, S.; et al. Depressive state and paresthesia dramatically improved by intravenous $\mathrm{MgSO}_{4}$ in Gitelman's syndrome. Intern. Med. 2004, 435, 410-414. [CrossRef]

36. Bhudia, S.K.; Cosgrove, D.M.; Naugle, R.I.; Rajeswaran, J.; Lam, B.K.; Walton, E.; Petrich, J.; Palumbo, R.C.; Gillinov, A.M.; Apperson-Hansen, C.; et al. Magnesium as a neuroprotectant in cardiac surgery: A randomized clinical trial. J. Thorac. Cardiovasc. Surg. 2006, 1314, 853-861. [CrossRef] [PubMed]

37. Pavlinac, D.; Langer, R.; Lenhard, L.; Deftos, L. Magnesium in Affective-Disorders. Biol. Psychiatry 1979, 144, 657-661.

38. Chouinard, G.; Beauclair, L.; Geiser, R.; Etienne, P. A Pilot-Study of Magnesium Aspartate Hydrochloride (Magnesiocard) as a Mood Stabilizer for Rapid Cycling Bipolar Affective-Disorder Patients. Prog. Neuropsychopharmacol. Biol. Psychiatry 1990, 142, 171-180. [CrossRef] 
39. Cox, I.M.; Campbell, M.J.; Dowson, D. Red-Blood-Cell Magnesium and Chronic Fatigue Syndrome. Lancet 1991, 3378744, 757-760. [CrossRef]

40. Arzoz-Fabregas, M.; Ibarz-Servio, L.; Fernández-Castro, J.; Valiente-Malmagro, M.; Roca-Antonio, J.; Edo-Izquierdo, S.; Buisan-Rueda, O. Chronic stress and calcium oxalate stone disease: Influence on blood cortisol and urine composition. Urology 2013, 826, 1246-1252. [CrossRef] [PubMed]

41. Kessler, R.C.; Aguilar-Gaxiola, S.; Alonso, J.; Chatterji, S.; Lee, S.; Ormel, J.; Ustün, T.B.; Wang, P.S. The global burden of mental disorders: An update from the WHO World Mental Health (WMH) surveys. Epidemiol. Psichiatr. Soc. 2009, 181, 23-33. [CrossRef]

42. Sartori, S.B.; Whittle, N.; Hetzenauer, A.; Singewald, N. Magnesium deficiency induces anxiety and HPA axis dysregulation: Modulation by therapeutic drug treatment. Neuropharmacology 2012, 621, 304-312. [CrossRef] [PubMed]

43. Pyndt Jørgensen, B.; Winther, G.; Kihl, P.; Nielsen, D.S.; Wegener, G.; Hansen, A.K.; Sørensen, D.B. Dietary magnesium deficiency affects gut microbiota and anxiety-like behaviour in C57BL/6N mice. Acta Neuropsychiatr. 2015, 2705, 307-311. [CrossRef] [PubMed]

44. Laarakker, M.C.; van Lith, H.A.; Ohl, F. Behavioral characterization of A/J and C57BL/6J mice using a multidimensional test: Association between blood plasma and brain magnesium-ion concentration with anxiety. Physiol. Behav. 2011, 1022, 205-219. [CrossRef] [PubMed]

45. Iezhitsa, I.N.; Spasov, A.A.; Kharitonova, M.V.; Kravchenko, M.S. Effect of magnesium chloride on psychomotor activity, emotional status, and acute behavioural responses to clonidine, $d$-amphetamine, arecoline, nicotine, apomorphine, and L-5-hydroxytryptophan. Nutr. Neurosci. 2011, 141, 10-24. [CrossRef] [PubMed]

46. Grases, G.; Pérez-Castelló, J.A.; Sanchis, P.; Casero, A.; Perelló, J.; Isern, B.; Rigo, E.; Grases, F. Anxiety and stress among science students. Study of calcium and magnesium alterations. Magnes. Res. 2006, 192, 102-106.

47. Mocci, F.; Canalis, P.; Tomasi, P.A.; Casu, F.; Pettinato, S. The effect of noise on serum and urinary magnesium and catecholamines in humans. Occup. Med. 2001, 511, 56-61. [CrossRef]

48. Takase, B.; Akima, T.; Uehata, A.; Ohsuzu, F.; Kurita, A. Effect of chronic stress and sleep deprivation on both flow-mediated dilation in the brachial artery and the intracellular magnesium level in humans. Clin. Cardiol. 2004, 274, 223-227. [CrossRef]

49. Held, K.; Antonijevic, I.A.; Künzel, H.; Uhr, M.; Wetter, T.C.; Golly, I.C.; Steiger, A.; Murck, H. Oral Mg2+ supplementation reverses age-related neuroendocrine and sleep EEG changes in humans. Pharmacopsychiatry 2002, 354, 135-143. [CrossRef] [PubMed]

50. Johnson, P.L.; Shekhar, A. Panic-Prone State Induced in Rats with GABA Dysfunction in the Dorsomedial Hypothalamus Is Mediated by NMDA Receptors. J. Neurosci. 2006, 2626, 7093-7104. [CrossRef] [PubMed]

51. Coan, E.J.; Collingridge, G.L. Magnesium ions block an N-methyl-D-aspartate receptor-mediated component of synaptic transmission in rat hippocampus. Neurosci. Lett. 1985, 53, 21-26. [CrossRef]

52. Masugi, M.; Yokoi, M.; Shigemoto, R.; Muguruma, K.; Watanabe, Y.; Sansig, G.; van der Putten, H.; Nakanishi, S. Metabotropic glutamate receptor subtype 7 ablation causes deficit in fear response and conditioned taste aversion. J. Neurosci. 1999, 193, 955-963.

53. Niswender, C.M.; Conn, P.J. Metabotropic glutamate receptors: Physiology, pharmacology, and disease. Annu. Rev. Pharmacol. Toxicol. 2010, 50, 295-322. [CrossRef] [PubMed]

54. Papadopol, V.; Nechifor, M. Magnesium in Neuroses and Neuroticism. In Magnesium and the Central Nervous System; Vink, R., Nechifor, M., Eds.; University of Adelaide Press: Adelaide, Australia, 2011.

55. Lydiard, R.B. The Role of GABA in Anxiety Disorders. J. Clin. Psychiatry 2003, 643, 21-27.

56. Lakhan, S.E.; Vieira, K.F. Nutritional and herbal supplements for anxiety and anxiety-related disorders: Systematic review. Nutr. J. 2010, 91, 1-14. [CrossRef] [PubMed]

57. Boyle, N.B. Call for unpublished findings. Magnes. Res. 2016, 29, 34.

58. Cazaubiel, J.M.; Desor, D. Evaluation of the anti-stress effects of a fermented milk containing milk protein hydrolysate on healthy human subjects sensitive to the stress of everyday life. Proprietary data cited in Scientific Opinion of the Panel on Dietetic Products, Nutrition and Allergies, No. 1924/20061. Eur. Food Saf. Auth. J Unpublished work. 2008, pp. 1-10.

59. Rouillon, F.; Lejoyeux, M.; Martineau, C. A Double-blind Controlled Study of PCR 7060 vs. Buspirone in the Treatment of Generalised Anxiety Disorder Conference Abstract. In Proceedings of the 8th European College of Neuropsychopharmacology Congress, Venice, Italy, 30 September-4 October 1995. 
60. Caillard, V. Sanofi Internal report MAB6-26. Paris, France, Unpublished work. 1992.

61. Caillard, V. Sanofi Internal report MAB6-32. Paris, France, Unpublished work. 1995.

62. Boyle, N.B.; Lawton, C.; Dye, L. The effects of magnesium supplementation on subjective anxiety. Magnes. Res. 2016, 293, 120-125.

63. Khine, K.; Rosenstein, D.L.; Elin, R.J.; Niemela, J.E.; Schmidt, P.J.; Rubinow, D.R. Magnesium (Mg) Retention and Mood Effects After Intravenous Mg Infusion in Premenstrual Dysphoric Disorder. Biol. Psychiatry 2006, 594, 327-333. [CrossRef] [PubMed]

64. Walker, A.F.; De Souza, M.C.; Marakis, G.; Robinson, P.A.; Morris, A.P.; Bolland, K.M. Unexpected benefit of sorbitol placebo in $\mathrm{Mg}$ intervention study of premenstrual symptoms: Implications for choice of placebo in RCTs. Med. Hypotheses 2002, 583, 213-220. [CrossRef] [PubMed]

65. Hamilton, M. The assessment of anxiety states by rating. Br. J. Med. Psychol. 1959, 32, 30-35. [CrossRef]

66. Moos, R.H. The development of a menstrual distress questionnaire. Psychosom. Med. 1968, 306, 853-867. [CrossRef]

67. De Souza, M.C.; Walker, A.F.; Robinson, P.A.; Bolland, K. A synergistic effect of a daily supplement for 1 month of $200 \mathrm{mg}$ magnesium plus $50 \mathrm{mg}$ vitamin B6 for the relief of anxiety-related premenstrual symptoms: A randomized, double-blind, crossover study. J. Womens Health Gend.-Based Med. 2000, 92, 131-139. [CrossRef] [PubMed]

68. Fard, F.E.; Mirghafourvand, M.; Charandabi, S.M.; Farshbaf-Khalili, A.; Javadzadeh, Y.; Asgharian, H. Effects of zinc and magnesium supplements on postpartum depression and anxiety: A randomized controlled clinical trial. Women Health 2016, 1-14. [CrossRef] [PubMed]

69. Walker, A.F.; Marakis, G.; Morris, A.P.; Robinson, P.A. Promising hypotensive effect of hawthorn extract: A randomized double-blind pilot study of mild, essential hypertension. Phytother. Res. 2002, 161, $48-54$. [CrossRef] [PubMed]

70. Borrello, G.; Mastroroberto, P.; Curcio, F.; Lucia Mazza, M. The effects of magnesium oxide on mild essential hypertension and quality of life. Curr. Ther. Res. 1996, 5710, 767-774. [CrossRef]

71. Spielberger, C.D. State-Trait Anxiety Inventory, 2nd ed.; Bibliography Consulting Psychologists Press: Palo Alto, CA, USA, 1989.

72. Hanus, M.; Lafon, J.; Mathieu, M. Double-blind, randomised, placebo-controlled study to evaluate the efficacy and safety of a fixed combination containing two plant extracts (Crataegus oxyacantha and Eschscholtzia californica) and magnesium in mild-to-moderate anxiety disorders. Curr. Med. Res. Opin. 2004, 201, 63-71. [CrossRef] [PubMed]

73. Zigmond, A.S.; Snaith, R.P. The Hospital Anxiety and Depression Scale. Acta Psychiatr. Scand. 1983, 676, 361-370. [CrossRef]

74. Bourgeois, M. Rôle du Magne-B6 dans les Manifestations Anxueuses en Pratique Medicale Courante Psychiatr. Pract. Med. 1987, 39, 18-22.

75. Scharbach, H. Anxiété et Magné B6. La Vie Médicale 1988, 17, 867.

76. Gendle, M.H.; O'Hara, K.P. Oral Magnesium Supplementation and Test Anxiety in University Undergraduates. J. Artic. Support Null Hypothesis 2015, 11, 21-30.

77. Driscoll, R. Westside Test Anxiety Scale Validation; Education Resources Information Center: Washington, DC, USA, 2007.

78. Muthayya, S.; Thomas, T.; Srinivasan, K.; Rao, K.; Kurpad, A.V.; van Klinken, J.W.; Owen, G.; de Bruin, E.A. Consumption of a mid-morning snack improves memory but not attention in school children. Physiol. Behav. 2007, 901, 142-150. [CrossRef] [PubMed]

79. Pollitt, E.; Cueto, S.; Jacoby, E.R. Fasting and cognition in well- and undernourished schoolchildren: A review of three experimental studies. Am. J. Clin. Nutr. 1998, 674, 779S-784S.

80. Markus, C.R.; Olivier, B.; Panhuysen, G.E.; Van Der Gugten, J.; Alles, M.S.; Tuiten, A.; Westenberg, H.G.; Fekkes, D.; Koppeschaar, H.F.; de Haan, E.E. The bovine protein alpha-lactalbumin increases the plasma ratio of tryptophan to the other large neutral amino acids, and in vulnerable subjects raises brain serotonin activity, reduces cortisol concentration, and improves mood under stress. Am. J. Clin. Nutr. 2000, 716, 1536-1544.

81. Schatzberg, A.F.; Nemeroff, C.B. The American Psychiatric Publishing Textbook of Psychopharmacology; APA Press: Washington, DC, USA, 2009.

82. Campbell, D.T.; Kenny, D.A. Primer on Regression Artifacts; Guildford Press: New York, NY, USA, 1999. 
83. Sramek, J.J.; Tansman, M.; Suri, A.; Hornig-Rohan, M.; Amsterdam, J.D.; Stahl, S.M.; Weisler, R.H.; Cutler, N.R. Efficacy of buspirone in generalized anxiety disorder with coexisting mild depressive symptoms. J. Clin. Psychiatry 1996, 577, 287-291.

84. Taylor, D.P. Buspirone, a new approach to the treatment of anxiety. FASEB J. 1988, 29, 2445-2452.

85. Quaranta, S.; Buscaglia, M.A.; Meroni, M.G.; Colombo, E.; Cella, S. Pilot study of the efficacy and safety of a modified-release magnesium $250 \mathrm{mg}$ tablet (Sincromag) for the treatment of premenstrual syndrome. Clin. Drug Investig. 2007, 271, 51-58. [CrossRef]

86. Canning, S.; Dye, L.; Waterman, M.; Orsi, N.; Ayres, J.; Simpson, N. A randomised, double-blind, placebo-controlled trial to test the efficacy of Hypericum perforatum (St. John's Wort) for the treatment of premenstrual syndrome. CNS Drugs 2009, 54, 506-515.

87. Fathizadeh, N.; Ebrahimi, E.; Valiani, M.; Tavakoli, N.; Yar, M.H. Evaluating the effect of magnesium and magnesium plus vitamin B6 supplement on the severity of premenstrual syndrome. Iran J. Nurs. Midwifery Res. 2010, 15, 401-405. [PubMed]

88. Facchinetti, F.; Borella, P.; Sances, G.; Fioroni, L.; Nappi, R.E.; Genazzani, A.R. Oral magnesium successfully relieves premenstrual mood changes. Obstet. Gynecol. 1991, 782, 177-181.

89. Walker, A.F.; De Souza, M.C.; Vickers, M.F.; Abeyasekera, S.; Collins, M.L.; Trinca, L.A. Magnesium supplementation alleviates premenstrual symptoms of fluid retention. J. Womens Health 1998, 79, 1157-1165. [CrossRef]

90. Steiner, M.; Haskett, R.F.; Carroll, B.J. Premenstrual tension syndrome: The development of research diagnostic criteria and new rating scales. Acta Psychiatr. Scand. 1980, 62, 177-190. [CrossRef] [PubMed]

91. Connolly, M. Premenstrual syndrome: An update on definitions, diagnosis and management. Adv. Psychiatr. Treat. 2001, 7, 469-477. [CrossRef]

92. Canning, S.; Waterman, M.; Dye, L. Dietary supplements and herbal remedies for premenstrual syndrome (PMS): A systematic research review of the evidence for their efficacy. J. Reprod. Infant Psychol. 2006, 244, 363-378. [CrossRef]

93. Firoz, M.; Graber, M. Bioavailability of US commercial magnesium preparations. Magnes. Res. 2001, 144, 257-262.

94. Lindberg, J.S.; Zobitz, M.M.; Poindexter, J.R.; Pak, C.Y. Magnesium bioavailability from magnesium citrate and magnesium oxide. J. Am. Coll. Nutr. 1990, 91, 48-55. [CrossRef]

95. Walker, A.F.; Marakis, G.; Christie, S.; Byng, M. Mg citrate found more bioavailable than other $\mathrm{Mg}$ preparations in a randomised, double-blind study. Magnes. Res. 2003, 163, 183-191.

(C) 2017 by the authors. Licensee MDPI, Basel, Switzerland. This article is an open access article distributed under the terms and conditions of the Creative Commons Attribution (CC BY) license (http:/ / creativecommons.org/licenses/by/4.0/). 